\title{
Tectonic history and the biogeography of the freshwater fishes from the coastal drainages of eastern Brazil: an example of faunal evolution associated with a divergent continental margin
}

\author{
Alexandre Cunha Ribeiro
}

The eastern Brazilian coastal drainages are of great biogeographical significance, because of their highly endemic fish faunas. Phylogenetic patterns suggest a close biotic relationship between the rivers that flow into the Atlantic and those on the adjacent upland crystalline shield. However, little has been said on the dynamics of the geological processes causally related to the cladogenetic events between these areas. Distributional and phylogenetic patterns suggest a close association with the geological history of the passive continental margin of South America, from the Cretaceous to the present day. In this area megadome uplifts, rifting, vertical movements between rifted blocks and the erosive retreat of the South American eastern continental margin are hypothesized as the main geological forces controlling the distribution of freshwater fishes. The tectonic activity associated with the break-up of Gondwana and separation of South America and Africa formed six megadomes that control most of the current courses of the main crystalline shield river basins. Except for basins located at the edges of such megadomes, these river systems developed long, circuitous routes over the ancient Brazilian crystalline shield before emptying into the recently opened Atlantic Ocean. Initial cladogenetic events between upland crystalline drainages and Atlantic tributaries were probably associated with vicariant processes, and some ancient basal sister-groups of widespread inclusive taxa are found in these coastal hydrographic systems. Later, generalized erosive denudation resulted in an isostatic adjustment of the eastern margin of the platform. These, along with reactivations of ancient rifts led to vertical movements between rifted blocks and gave rise, in southeastern Brazil, to taphrogenic (rift related) basins. These basins, such as the Taubaté, São Paulo, Curitiba and Volta Redonda basins, among others, captured adjacent upland drainages and fauna. The fossil fishes from the Tremembé Formation (Eocene-Oligocene of Taubaté Basin) exemplify this process. Other taphrogenic systems of Tertiary age were also identified in other segments of the Atlantic continental margin, such as in Borborema province, in NE Brazil, with marked influence over drainage patterns. At the same time, erosive retreat of the eastern margin of the platform successively captured upland rivers, which became Atlantic tributaries evolving associated to main rift systems. The continued nature of these processes explains the mixed phylogenetic and distributional patterns between Atlantic tributaries and the upland crystalline shield areas, especially in the southeastern continental margin, represented by successively, less inclusive sister-groups associated with cladogenetic events from the Late Cretaceous to the present.

As drenagens costeiras do leste do Brasil correspondem a áreas de grande significado biogeográfico, apresentando um alto grau de endemismo em sua fauna de peixes. Padrões filogenéticos sugerem uma relação próxima entre os rios que correm para o Atlântico a os adjacentes das terras altas do escudo cristalino. Entretanto, pouco tem sido dito sobre a dinâmica dos processos geológicos relacionados aos eventos cladogenéticos entre estas áreas. Padrões de distribuição e filogenéticos sugerem uma íntima associação com a história geológica da margem continental passiva da América do Sul, desde o Cretáceo aos dias atuais. Soerguimentos macrodômicos, rifteamento, movimentos verticais entre blocos falhados e o recuo erosivo da margem leste sul-americana são considerados como as principais forças geológicas atuando sobre a distribuição da ictiofauna de água doce nestas áreas. A atividade tectônica associada à ruptura do Gondwana e separação da América do Sul e África criou seis megadomos que são responsáveis por configurar a maior parte do atual curso das principais bacias hidrográficas do escudo cristalino. Com exceção das bacias localizadas às margens de tais megadomos, estes rios desenvolveram longos e sinuosos circuitos sobre o antigo escudo cristalino brasileiro antes de desaguarem no então recentemente aberto Oceano Atlântico. Eventos cladogenéticos iniciais entre drenagens de terras altas do escudo cristalino e tributários do Atlântico podem estar associados com processos vicariantes desta fase inicial, e alguns táxons antigos, basais, grupos-irmão de táxons

Institutional affiliation: Departamento de Zoologia (IBB-UNESP), Caixa Postal 510, 18618-000 Botucatu, SP, Brazil.

Mailing address: Laboratório de Ictiologia de Ribeirão Preto (LIRP), Departamento de Biologia, FFCLRP-USP, Av. Bandeirantes, 3900 , 14040-901 Ribeirão Preto, SP, Brazil. email: acribeiro@click21.com.br 
muito inclusivos e de ampla distribuição são encontrados nestas bacias hidrográficas. Mais tarde, a denudação erosiva generalizada resultou em um ajuste isostático da margem leste da plataforma. Tal ajuste, concomitantemente a reativações de antigas zonas de falha, resultou em movimentos verticais entre blocos falhados, dando origem, no sudeste do Brasil, a bacias tafrogênicas. Tais bacias, como a de Taubaté, São Paulo, Curitiba e Volta Redonda, entre outras, capturaram drenagens e fauna de terras altas adjacentes. Os peixes fósseis da Formação Tremembé (Eoceno-Oligoceno da Bacia de Taubaté) exemplificam este processo. Outros sistemas tafrogênicos de idade Terciária foram também identificados em outros segmentos da margem continental Atlântica, como na Província Borborema, no NE do Brasil, com marcada influência sobre o padrão de drenagem. Ao mesmo tempo, o recuo erosivo da margem leste da plataforma capturou sucessivamente rios de planalto, os quais se tornaram tributários atlânticos, evoluindo associados aos principais sistemas de falha. A natureza continuada destes processos explica os padrões filogenéticos e de distribuição miscigenados entre os tributários atlânticos e as terras altas do escudo cristalino adjacente, especialmente na margem sudeste do continente, representados por sucessivos, cada vez menos inclusivos, grupos irmãos, associados a eventos cladogenéticos desde o final do Cretáceo ao presente.

Key words: Fishes, Distributional Patterns, Passive Margin, South America, Tectonics.

\section{Introduction}

The Neotropical freshwater ichthyofauna is the most diversified in the world, with more than 4,000 described species (Reis et al., 2003). The actual number of species, however, could reach 8,000 according to recent estimates (Schaefer, 1998; Vari \& Malabarba, 1998). The reasons for such a pronounced diversity are likely to be both historical and ecologi$\mathrm{cal}$ - a result of millions of years of evolution from the break up of Gondwana to the present.

The biogeography of the Neotropical ichthyofauna, however, is poorly known. According to Vari \& Weitzman (1990), three major factors limit the precision of hypotheses about the historical biogeography of South American freshwater fishes: 1) the poor state of knowledge of the species-level systematics of most taxa; 2 ) inadequate distributional information for most species, and; 3) sparse or non-existent data on the phylogenetic history of most supraspecific taxa. An additional reason can be added: 4) the difficulties in associating phylogenetic hypotheses and the known geological history of the continent. If biogeography is, as defined by Nelson (1985), "the interrelationship, or synthesis, of geology and biology", the difficulties of biologists in understanding and synthesizing geological processes constitute a serious limitation to our knowledge of the biogeography of Neotropical freshwater fishes.

Most of the information available on the biogeography of Neotropical freshwater fishes comes from phylogenetic data derived from revisionary studies of particular groups, in which attempts were made to clarify relationships between areas of endemism based on analyses of area cladogram (e.g. Vari, 1988; Schaefer, 1997; Reis, 1998; Vari \& Harold, 2001; Costa, 2001). When available, geological inferences in these studies were made based on major well understood geological events, such as the uplift of the Andean cordilleras.

Recently, Lundberg et al. (1998) provided a detailed chronological synthesis of the geological history of South America written for ichthyologists in general. Their very useful contribution focuses, however, on the uplift of the Andean cordilleras, major seaway transgressions along the slope of the Andes along the western margin of the South American Plat- form, and the paleodrainages of the northwest and northern portions of the continent in the Guyana Shield and Amazon basin. Few data were provided about the remaining areas of the South American Platform, where large hydrographic basins, such as the Paraná-Paraguay, São Francisco and the closely related Atlantic slope coastal rivers, drain the oldest terrenes of the continent: the ancient Brazilian crystalline shield.

The aim of this paper is to provide an overview of the principal aspects of geological history of the passive continental margin of eastern South America and explain the biogeographic history of the fish fauna from the Brazilian crystalline shield, focusing mainly on the coastal drainages of eastern Brazil, with a special emphasis on the southeastern continental margin. This area has an ancient biogeographic component as exemplified by the occurrence of several groups of fishes, which are phylogenetically basal to widespread clades that underwent subsequent diversification in most hydrographic basins in South America. These early cladogenetic events were associated with the initial stage of the geomorphological evolution of the eastern South American continental margin, involving tectonics and erosive process that took place during and after the break up of Gondwana. These processes are, to a degree, still active today.

\section{Continental geological overview}

The South American Platform (Fig. 1) is defined, as the stable continental portion of the South American plate not affected by the Caribbean and Andean orogenic zones (Almeida et al., 2000). It is formed by the Brazilian Platform and by the Patagonian Platform. The structural provinces of the South American Platform are identified according to their origin as the cratonic areas, ancient orogenic belts, and sedimentary basins (Almeida et al., 1981), as indicated in Fig. 1.

Cratons represent the most stable region of the continent composed of Precambrian rocks. During orogenic cycles, these areas behave as rigid blocks, with mobile belts developing around them. When eroded and exposed, cratons are called shields (Penha, 1998). The South American Platform has the following cratons: Amazonian, São Francisco, Rio de la Plata, São Luiz, and Luiz Alves (Cordani et al., 2000) (Fig. 1). 


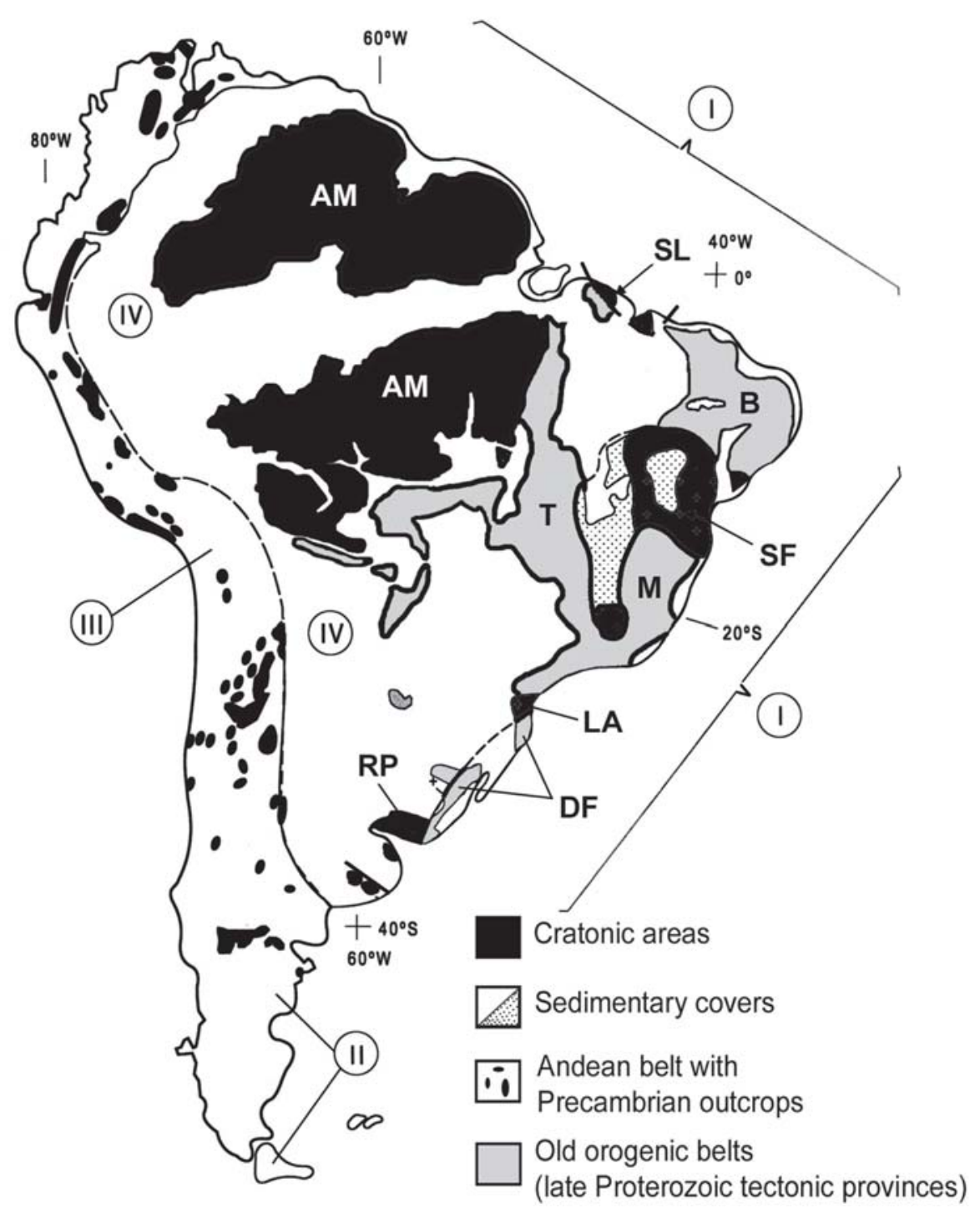

Fig. 1. Crustal provinces of South America. I - South American Platform; II - Patagonian massif; III - Andean orogenic belt; IV - foreland basins; $\mathrm{AM}=$ Amazon craton; $\mathrm{SL}=\mathrm{São}$ Luis craton; $\mathrm{SF}=\mathrm{São}$ Francisco craton; $\mathrm{LA}=$ Luiz Alves craton; $\mathrm{RP}=\mathrm{Rio}$ de la Plata craton; $\mathrm{B}=$ Borborema province; $\mathrm{T}=$ Tocantins province; $\mathrm{M}=$ Mantiqueira province; $\mathrm{DF}=$ Dom Feliciano belt. (Modified from Cordani et al., 2000 and Cordani \& Sato, 1999).

The same mobile interactions between plates that occur today also occurred during most of the geological history of the earth, during which different portions of present day South America were involved in the amalgamation and break-up of several ancient super-continents during the so-called orogenic cycles, such as the Atlantida (Paleoproterozoic), Rodinia (Mezoproterozoic), Western Gondwana (Neoproterozoic), and Pangea (Carboniferous) supercontinents (Cordani et al., 2000; Saenz et al., 2003). A result of this continental amalgamation was the development of an orogenic or mobile belt. Most of the ancient orogenic belts found in the South American Platform are derived from three main sets of orogenic events: 1) Trans-Amazonian (Paleoproterozoic); 2) late Mesoproterozoic and; 3) Brasiliano/Pan African (Almeida et al., 2000). Most of the orogenic structural provinces of the South American Plat- form resulted from the Brasiliano/Pan African orogenic cycle, when several cratonic nuclei (Amazonian, São Francisco, São Luiz, Rio de la Plata, in South America and the West African, Kongo and Kalahari in Africa) amalgamated in the Western Gondwana continent between 750 and $530 \mathrm{Ma}$ (Cordani et al., 2000). As shown in Fig. 1, the ancient orogenic belts of the South American Platform are the Borborema, Mantiqueira and Tocantins provinces, and the Dom Feliciano belt. Today, the metamorphic rocks present in these areas (meta-volcano-sedimentary rocks) represent the roots of those eroded ancient mountain chains of orogenic origin.

In the South American Platform, sedimentary basins evolved in a different set of tectono-sedimentary domains, as shown in Fig. 2. These are: 1) the continent's interior, filled primarily by Paleozoic and Mesozoic sedimentary sequences, 


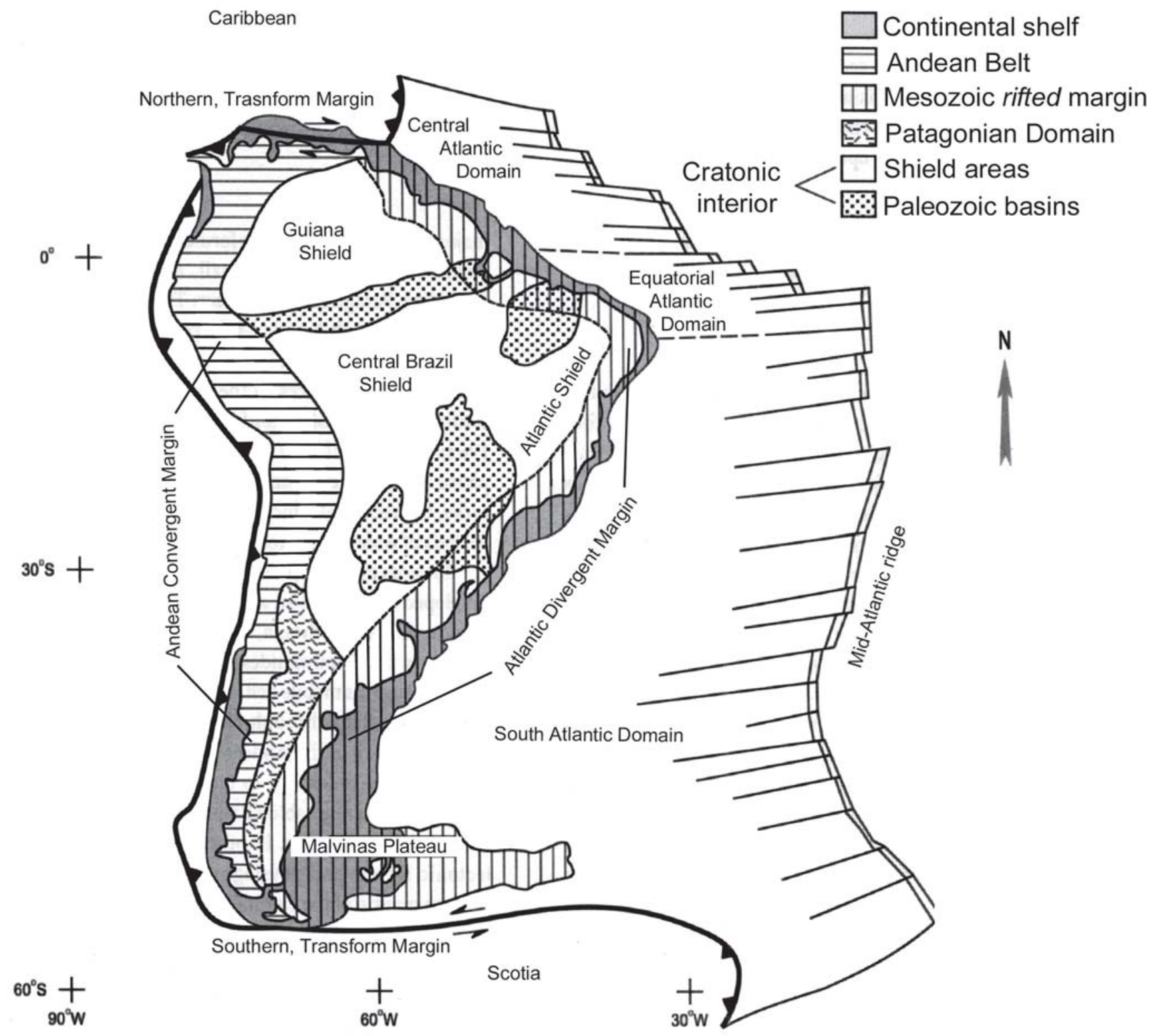

Fig. 2. The South American Plate and its major tectono-sedimentary domains (from Milani \& Thomaz-Filho, 2000).

but also by Cenozoic sequences; 2) the western, convergent continental domain, the Andean chain, with its related sedimentary basins; 3 ) the northern and southern margins of the South American plate, where its contact and interacts with the Caribbean and Scotia plates, and; 4) the eastern, divergent continental margin of the continent that is derived from the break-up of South America and Africa, where the sedimentary sequence evolved in different sets of sedimentary environments and tectonic phases since the Mesozoic (Milani \& Thomaz-Filho, 2000) (Fig. 2).

Associated with the main structural and tectonic sedimentary provinces in the South American Platform are complex systems of ancient faults, as well as widespread intrusive and extrusive volcanism. These are heritages of the continental amalgamation during the orogenic cycles together with the rifting process related to the break-up of the precursor super-continent in which the present day South America was involved. Rifting and magmatism associated with the break-up of Gondwana are found in most tectonic and sedimentary provinces of the South American Platform (ThomazFilho et al., 2000).

\section{Tectonic evolution of the eastern margin of South America}

The eastern margin of the South American Platform belongs to a kind of continental margin known as "Passive" or "Atlantic-Style" margin. According to Moores \& Twiss (1995), in this kind of margin, the continental basement is more slender toward the margin as a result of extensive faulting. In some regions, fault-bounded basins (taphrogenic basins) of continental deposits are present on top of the crystalline base- 


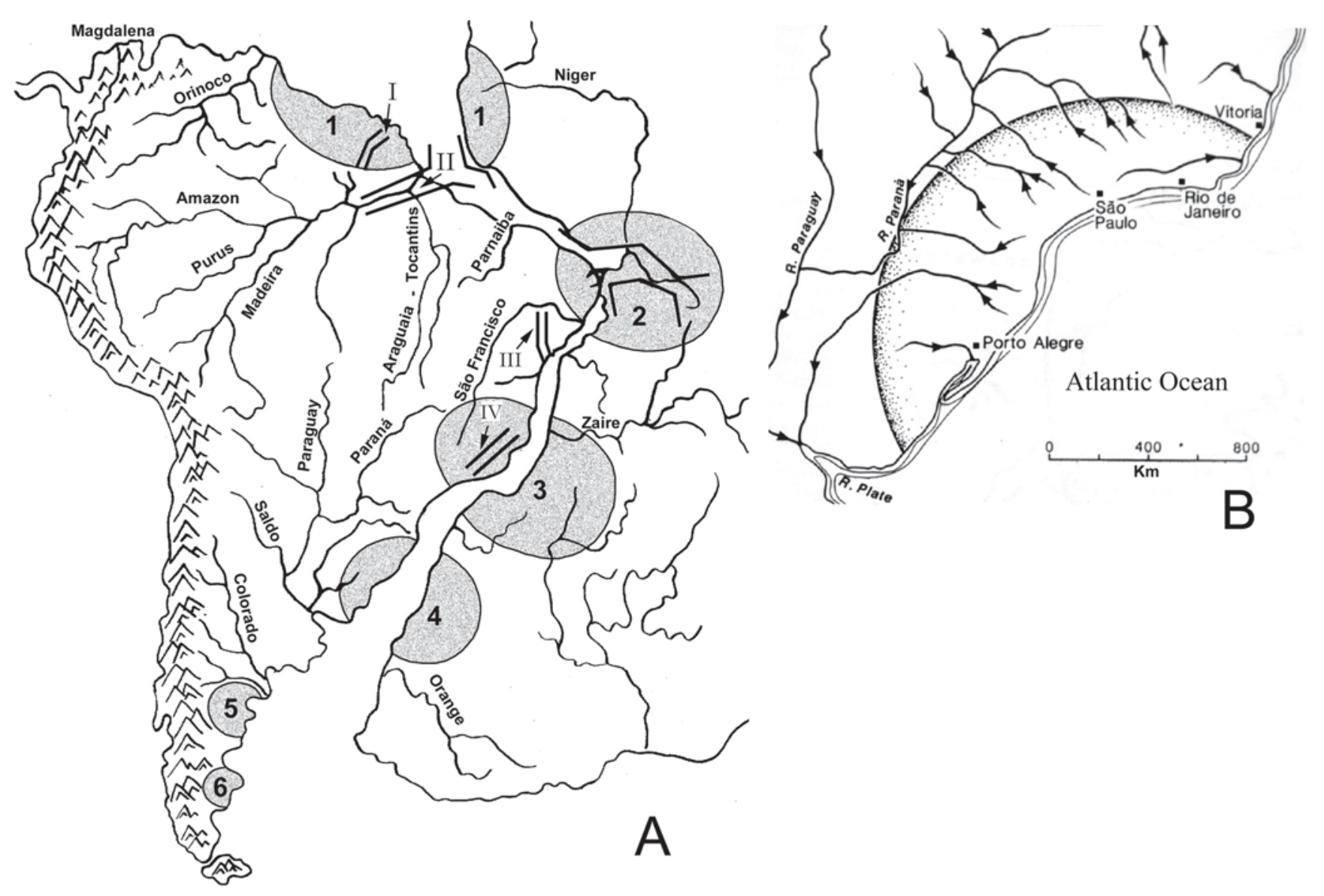

Fig. 3. Rivers and uplifts of Atlantic South America. A) break-up uplifts (megadomes) and associated principal rifts. Megadomes: Guyana/Guinea (1), NE Brazil/Niger (2), Mantiqueira/Angola (3), Uruguay/SW Africa (4), Somuncurá (5) and Deseado (6). Break-up rifts: Tacutu (I), Foz do Amazonas (II), Reconcavo Tucano-Jatobá (III) and Taubaté (IV). B) detail of the uplift from the Southeastern Brazil (from Cox, 1989 and Potter, 1997).

ment. There are, in addition, flows of igneous rocks within the upper stratigraphic levels of the rift valley sediments (Moores \& Twiss, 1995). According to Thomas (1995) and Vitte (2001), there are six major tectonic features controlling the long-term morphological evolution of passive margins: 1) uplift controlled by the action of hot spots (thermal driven uplift); 2) isostatic uplift due to denudation and unloading on emerged areas; 3 ) thermally driven subsidence; 4) isostatic subsidence due to sediment loading offshore; 5) rotation of continental margin resulting from 4; and 6) escarpment erosive retreat.

The tectonic processes responsible for imposing the "Atlantic-Style" of the eastern margin of the South America Platform are ancient, probably active since the Triassic, representing the initial phase of the break-up of Gondwana.

The chronology of the South American and African breakup indicates distinct phases of magmatic activity related to a rifting process (Thomaz-Filho et al., 2000). The first rifting began on the Brazilian equatorial margin from French Guyana to the Amazon delta in the Marajó basin between 230 and 170 million year ago, with two phases of a more pronounced magmatic activity (during Triassic and Jurassic times). Rifting also took place during the Triassic, in the southern portion of South America as deduced by the presence of significant riftrelated Triassic magmatic rocks in the marginal San Julian and North Malvinas basins. Between 170 and 120 million years ago, rifting took place along the Argentinean, Uruguayan and Brazilian coasts reaching as far as Espírito Santo basin. At the same time, the clockwise rotation of South America resulted in wrenching between faults that were occurring on the northeastern Brazilian equatorial margin (Thomaz-Filho et al., 2000).

Beginning in the Triassic, the paleogeography of the Atlantic continental margins of South America and Africa underwent dramatic change due to a major tectonic event: the Wealdenian Reactivation (Almeida, 1967; Cesero \& Ponte, 1997) or South Atlantic Event (Schobbenhaus et al., 1984). In the initial phase, between the Triassic and Jurassic period, a single, large, longitudinally elongated basin (extending from 0 to $20^{\circ} \mathrm{S}$ ) the Afro-Brazilian Depression, arose due to the rifting process (Da Rosa \& Garcia, 2000). This basin captured the adjacent drainages thereby giving rise to an interconnected lake system, similar to that of present day eastern African lakes. The Afro-Brazilian Depression continued to 
evolve as a consequence of the processes of tectonic breakup (Da Rosa \& Garcia, 2000). It has been suggested that the Afro-Brazilian Depression became divided into a set of smaller basins during the rift phase, following the primary axes of fault systems of the eastern Brazilian margin (for example, the Souza, Igatú, Jatobá and Araripe basins, associated to the Patos and Pernambuco fault lineaments, in the northeastern Brazil) (Da Rosa \& Garcia, 2000). As a consequence of the reactivation, there also arose several new fault systems along the coast and in the Brazilian interior, as well as the rise of several rift basins. Examples of these basins are the Tacutu and the Marajó graben, in northernmost Brazil, neighboring Guiana, and in the Amazon delta, respectively; the complex system of rift basins Recôncavo-Tucano-Jatobá, São Luiz and Barreirinhas in northeastern Brazil, among others (Potter, 1997; Milani \& Thomaz-Filho, 2000).

The African and the South American continents became completely separated between 98 and 93 million years ago (end of middle Cretaceous) (Cesero \& Ponte, 1997). From that period to the present continental drift has occurred between these two continents, with peaks of magmatic activities in the Eocene and Oligocene. In some cases, such activity was a consequence of hot spots, such as that responsible for the alignment between the Poços de Caldas/Cabo Frio continental alkaline rocks to the volcanic chain of Vitória/Trindade in the offshore area of southeastern Brazil (Almeida et al., 1996; Thomaz-Filho \& Rodrigues, 1999; Thomaz-Filho et al., 2000). Recently, an alternative nonplume related heat source for the generation of intracontinental magmatic provinces has been proposed to explain the occurrence of magmatic bodies in South America (Ernesto et al., 2002).

Among the most important implications for the biogeography of the aquatic continental biota resulting from the South Atlantic event is the tectonically imposed paleodrainage of the Brazilian crystalline shield. According to the model described by Cox (1989), upper mantle plumes created an arched deformation hundreds of kilometers in width during the initial phase of rifting that imposed a characteristic drainage pattern, with rivers running out from the center of the megadome deformation. This process supposedly acted on several portions of the continental margins of Africa and South America, giving rise to six main magadomes (Potter, 1997). The drainage patterns created by these areas of uplift are still evident, as shown in Fig. 3. Of all the major South American rivers, the Paraná seems to have the most perfect fit to those structures (Potter, 1997); however, this tectonic pattern is also evident in the headwaters and mouth of the rio São Francisco (Fig. 3). Other than those rivers that evolved along edge of these arched deformations, the Mesozoic reactivation resulted in drainage patterns in which the river systems developed long, circuitous routes over the ancient Brazilian crystalline shield before discharging into the recently opened Atlantic Ocean (Potter, 1997).

With the end of the reactivation and of the related complete break-up of Gondwana, the history of independent South American Atlantic rivers began. These rivers form a series of isolated hydrographic basins known as the Coastal Drain- ages of Eastern Brazil, with the primary hydrographic systems being the rios Paraguaçú, Contas, Jequitinhonha, Doce, Paraíba do Sul, Ribeira de Iguape, Itajaí and Jacuí (Fig. 4). These, along with several other smaller isolated basins, are separated by the scarped, mountainous landscapes of the eastern margin of the Brazilian crystalline shield.

Along the eastern coastal margin of South America, the post-Cretaceous history of the southeastern segment of the continent, in southeastern Brazil, is better understood. According to Cobbold et al. (2001), the obliquely rifted margin of southeastern Brazil is characterized by a tectonic context that contrasts with the traditional view in which the Atlantic margin of Brazil is a passive margin. These authors interpret the late Cretaceous and Cenozoic reactivation of older structures, attributing them to the combined effect of far-field stress (related to the Andean uplift) and hot-spot activity (the Trindade hot-spot). A large number of seismic events are reported in southeastern Brazil related to neighbouring regions. Patterns of topography and drainages provide evidence of recent uplift, block faulting and river capture, all of which are symptomatic of active tectonics. Inland, the crust of the region appears to be thicker than normal and decidedly thicker than what is expected for a rifted margin, probably due to Cenozoic shortening that originated from the action of continent-wide compressional stress. The lithosphere of southeastern Brazil is relatively weak relative to adjacent cratonic areas, and weaknesses probably explain why this region is seismically active and prone to deformations. Alkaline intrusions of Late Cretaceous-Paleogene age are relatively common and related to hot-spot activity or fault reactivation. Onshore and offshore geological evidence leads to the conclusion that the margin of southeastern Brazil was reactivated in three main phases and separated by quieter intervals that coincide with the Peruvian (90-75 Ma), Incaic (50-40 Ma) and Quechuan (25-0 Ma) phases of Andean orogeny, which occurred during periods of relatively rapid convergence at the Andean margin of South America. Also, the kinematics of Cenozoic deformation in southeastern Brazil is compatible with the changing directions of convergence at the Andean margin, which was highly oblique in the Paleogene and much less so in the Neogene (Cobbold et al., 2001).

Almeida \& Carneiro (1998) provided geological evidence that, at the end of the Cretaceous, the southeastern Brazilian crystalline shield extended eastward into the present day inner continental platform. The shield extended to the edge of the Santos Basin, an offshore sedimentary basin now filled with about 13,000 $\mathrm{m}$ of sediments, the oldest of which dates back to the Late Cretaceous (100 Ma). This Late Cretaceous sedimentary sequence of the Santos Basin is the counterpart of the sequence of the same age found in the Baurú group (Paraná Basin), and both represent the erosive denudation cycle of the Brazilian crystalline shield that has taken place along the eastern margin of the continent from that period to the present (Fig. 5). The continental crust of southeastern Brazil suffered a vertical denudation of about $3 \mathrm{~km}$, exposing deep metamorphic rocks of the ancient Ribeira and 


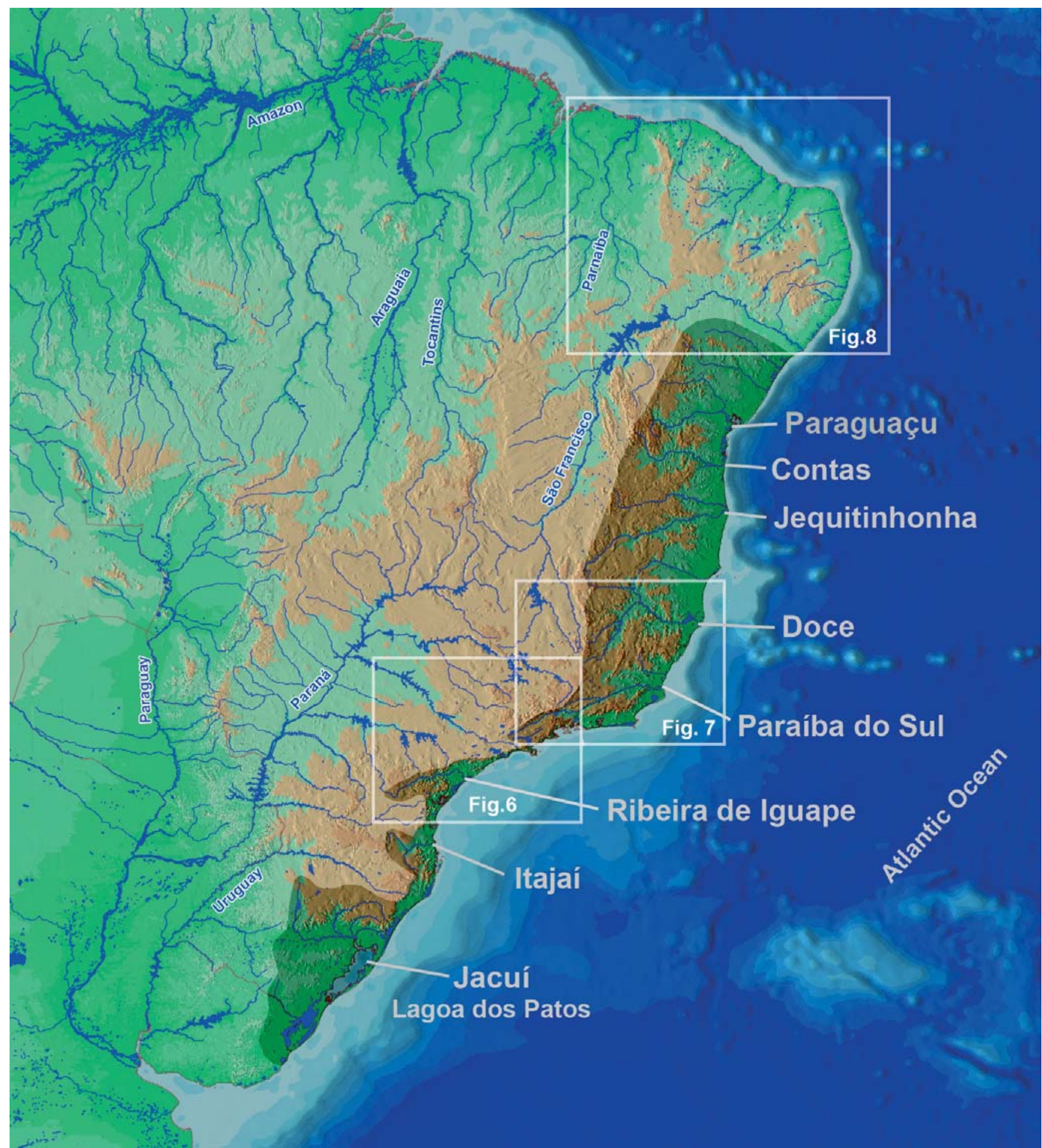

Fig. 4. Geographic location of the Brazilian Atlantic continental margin and of the coastal drainages of eastern Brazil (shaded area) and areas showed in figures 6, 7 and 8 (modified from Hearn et al., 2000).

Mantiqueira orogenic belts (Gallagher et al., 1994). According to Almeida \& Carneiro (1998), the reduction of weight as a consequence of the erosive process in the crust, and its increase in offshore basins, provided an uplift of the former and lowering of the latter due to an isostatic adjustment. The isostatic epirogenesis of the eastern margin of the South
American Platform also resulted in movements between rifted blocks (reactivation of old rifts), and was the main reason for the origin of several taphrogenic basins or grabens (basins originating by the lowering of rifted blocks) such as that of the "Serra do Mar Rift System," which includes the Taubaté, São Paulo, Resende, Volta Redonda, Curitiba, Sete Barras, 


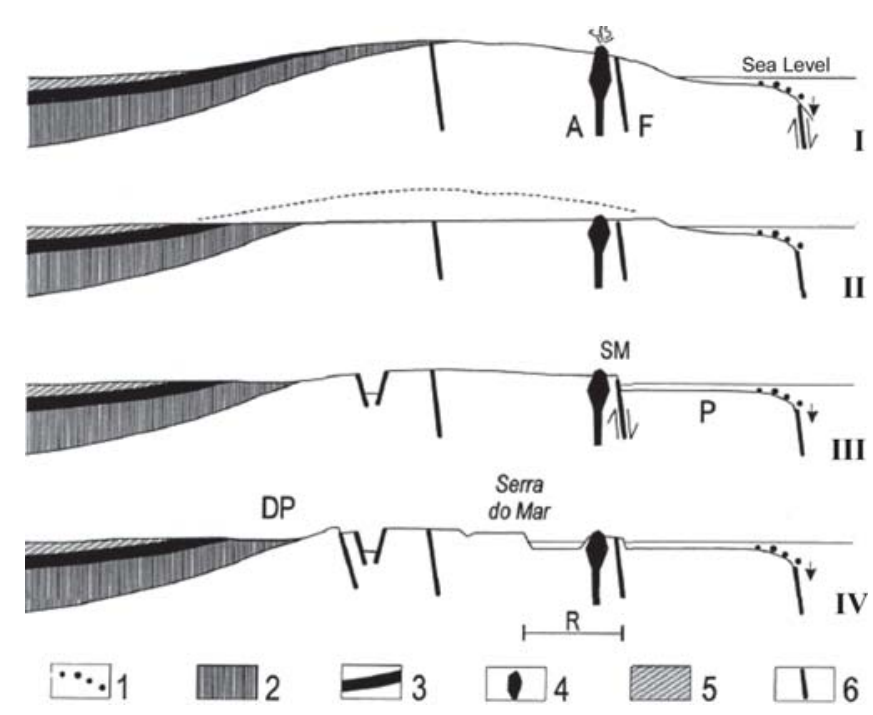

Fig. 5. Schematic diagram of origin and erosional SE-NW retreat of Serra do Mar coastal range in region between inland Paraná basin, and the Santos basin, coast of SE Brazil. 1Eroded Senonian uplift, allowing deposition in both Santos and Paraná basins. Alkaline volcanism (A); Santos Fault (F). 2- Development of the Japi Erosional Surface at the end of Senonian. 3- Paleocene deformation of the Japi Surface (isostatic adjustment). Serra do Mar (SM) is generated at Santos Fault (F), system of continental rifts originated and continental platform formed in coast $(\mathrm{P})$. 4- Erosional retreat $(\mathrm{R})$ of Serra do Mar toward present position. The approximate position of Depressão Periférica is indicated (DP). Alkaline intrusions represent islands. Conventions: 1. Santos formation deposits, 2. Phanerozoic cover beneath the Serra Geral basalt, 3. Serra Geral Formation, 4. Alkaline bodies, 5. Bauru Group, 6. Faults (from Almeida \& Carneiro, 1998).

and Guanabara Depression basins (Almeida, 1976; Almeida \& Carneiro, 1998) (Fig. 6). These movements also led to vertical movements recently reported for other areas, such as that responsible of the origin of the Cananéia and the Barra de São Joaquim grabens in the states of São Paulo and Rio de Janeiro (Souza et al., 1996; Mohriak \& Barros, 1990). However, according to Riccomini et al. (2004) these basins originated due to reactivations of the sub-parallel NE to E-W Precambrian shear zones, know as the Continental Rift of Southeastern Brazil (CRSB). This tectonic feature initially named as the "Serra do Mar Rift System" (Almeida, 1976) is now identified as one of the largest structural discontinuities of the South American Platform, extending considerably beyond the Serra do Mar itself. The CRSB is an elongate narrow trough, over $900 \mathrm{~km}$ long, and roughly parallels the present-day coast line of southeastern Brazil, reaching the Atlantic Ocean in the northeast of the State of Rio de Janeiro (Riccomini et al., 2004) (Figs. 6 and 7).

The evolutionary history of the CRSB was the focus of several theories (Riccomini et al., 2004), along with the most recent recognizes that the system evolved in response to an combined effect of tectonic forces related to the spreading rates in the Middle Atlantic Ridge (ridge-push); far-field compressional stress related to the Andean orogeny (slab-pull); the activity of the Trindade hot spot; isostatic adjustments due to relief of height after extensive erosion of the ancient Brazilian shield; effects of the subsidence of the adjoining offshore Santos Basin; and oscillation of water pressures over the continental platform related to sea level changes during the Late Pleistocene (Almeida \& Carneiro, 1998; Riccomini \& Assumpção, 1999; Cobbold et al., 2001; Riccomini et al., 2004). According to recent models, during the Paleogene reactivation of Precambrian shear zones as normal faults was responsible for creating the original depression encompassing all the basins of the central to northeastern segment of the rift. In the Neogene, probably during the Miocene, reactivation of the rift was responsible for the first deformational event. In the Late Pleistocene-Holocene, a second deformational event took place; faults located at the edges of the basin were reactivated and gave rise to structural highs that configure the separation of the Paleogene sedimentary record in different basins. A third deformational event in the Holocene has been confirmed and there are evidences for the action of a younger stress field active until the present-day (Riccomini \& Assumpção, 1999). These deformational processes were basement-controlled, mostly resulting from reactivation of Precambrian shear zones (Riccomini et al., 2004).

The escarpment erosive retreat was concomitant with the tectonic deformations described above and these together delimited the evolution of drainage patterns. Due to the breakup of Gondwana, several old faults were reactivated in discontinued pulses from the end of the Cretaceous to the Tertiary. The rocks of the reactivated faults, with their lesser resistance to erosion, govern the plan of the drainage pattern (Almeida \& Carneiro, 1998). With the continued erosive retreat, various rivers of the upland crystalline shield were captured, primarily along rift systems, to become Atlantic Ocean tributaries; a process that is still active in the present.

The generalized model of drainage pattern evolution involving isostatic epirogenesis, tectonic activity and the E-W erosive retreat of the eastern margin of the South American

Fig. 6. [next page] (a) Map of southern and central segment of the CRSB adjacent to Santos basin, between the States of Santa Catarina and Rio de Janeiro. 1 to 7: Continental taphrogenic basins: Curitiba (1), Cananéia (2), Sete Barras (3), São Paulo (4), Taubaté (5), Resende and Volta Redonda (6), Macacu, São José de Itaboraí and Barra de São João (7) (b) Detail of the Taubaté Basin produced from a digital elevation model by radar interferometry (NASA, The Shuttle Radar Topography Mission). (c) Detail of the mouth of the rio Ribeira de Iguape produced from a digital elevation model by radar interferometry (NASA, The Shuttle Radar Topography Mission) showing the gap in the Serra do Mar scapments resulted from the erosive action of this river into the Pre-Cambrian shear and rift zones (sources: Almeida \& Carneiro, 1998; Hearn et al., 2000; Bizzi et al., 2001). 


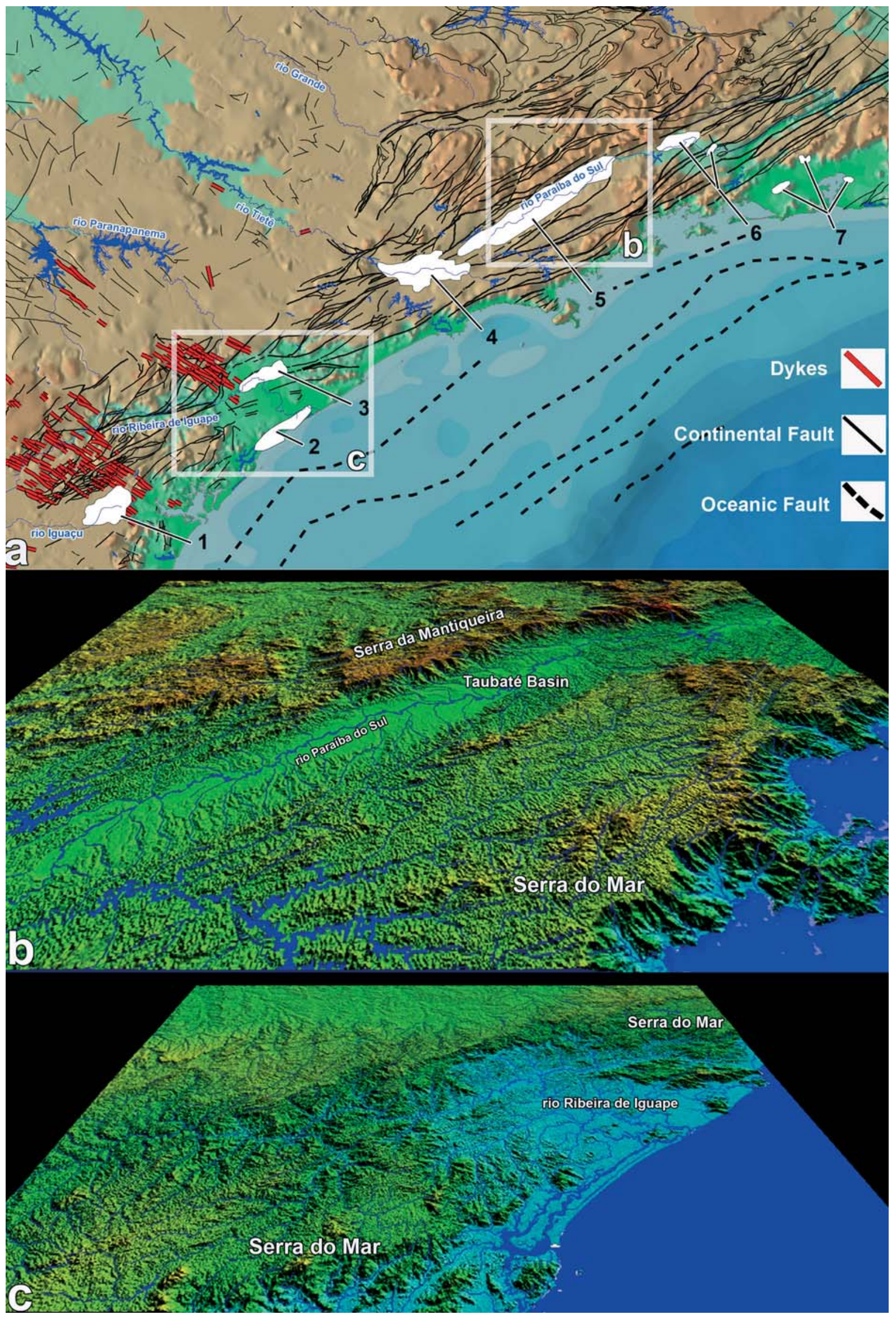


Platform predicts that the river systems associated with the main fault systems which are more susceptible to erosion will capture the headwaters of some crystalline shield tributaries. At the same time, vertical movements between faulted blocks gave rise to taphrogenic basins, which capture surrounding headwaters, originating a complex hydrography, sometimes represented by interconnected lake systems. Resistant areas, such as the complex systems of intruded basalts and other metamorphic rocks, sustain upland and become exposed in steep scarps (Almeida \& Carneiro, 1998). One of the most outstanding examples of such a process is the erosive retreat of the Ribeira de Iguape basin, which is responsible for carving a gap in the coastal Serra do Mar range, between São Paulo and Paraná States. This resulted from the erosive retreat of this river system in the Lancinha-Cubatão rifted zone (Almeida \& Carneiro, 1998) (Fig. 6c).

The evolution of taphrogenic basins are of crucial importance for the hydrographic system established between the end of the Cretaceous to the Tertiary. Once developed, these basins were responsible for headwater captures between adjacent upland hydrographic systems. In the case of the Taubaté basin, the capture of an arm of the rio Tietê was previously reported by Ab'Sáber $(1957,1998)$; however, this was not the only paleohydrological consequence of that taphrogenic event. The origin of the Taubaté Graben probably resulted in the capture of several other adjacent rivers, such as headwaters of the rivers Tietê, Grande, São Francisco, and probably Doce. The strategic position of the Taubaté Graben, in the core of the Mantiqueira-Angola regional megadome, from where headwaters of all the quadrants originate (Fig. 3) (Ab'Sáber, 1998), suggests a much more complicated hydrological history than is usually proposed by some simplified biogeographic scenarios (see e.g. Malabarba, 1998).

Tertiary taphrogenic system was also detected in northeastern Brazil, in the Borborema Province (Brito Neves et al., 2004). Reactivations along ancient faults during Paleogene times created a system of grabens and horsts, which are evident in present day landforms (the Cariatá and rio Mamanguape grabens, respectively) and the adjacent upland (the Boqueirão horst) in the State of Paraíba, NE Brazil (Fig. 8). This taphrogenic system imposes a tectonic control over the local hydrography, capturing to the Cariatá Graben segments of the local drainages, and deviating the upper stretch of the rio Paraíba from a N-S direction to its local E-W direction to the coast (Brito Neves et al., 2004). These more local phenomena illustrate how tectonic activities control drainage evolution in all scales along the eastern rifted continental margin of the Brazilian Platform (Figs. 6-8).

According to Riccomini \& Assumpção (1999), the concept of Quaternary tectonic stability prevailed for most of the Brazilian Platform and, because of this fact, investigation of Quaternary tectonics in Brazil has began to develop only in the last decade. The summary of Quaternary tectonics in Brazil presented by these authors indicates the existence of Quaternary, particularly Holocene, faulting in almost all Brazilian geological provinces. Among these, the region of the Continental Rift of Southeastern Brazil underwent the most pronounced and recent activities and reactivations of ancient structural lines (faults and shear zones) and generation of new faults (Riccomini \& Assumpção, 1999). This Quaternary tectonic activity causes, among other topographic changes, recent drainage rearrangements caused by stream captures (Modenesi-Guattieri et al., 2002). Saadi (1993) and Saadi et al. (2002) interpret the Quaternary tectonics in Brazil as being the result of reactivation along ancient crustal discontinuities (Pre-Cambrian and Mesozoic rift and shear zones) that behave as weakness zones and are more prone to undergo deformations.

During the Pleistocene and Holocene the coast of South America underwent marine transgressions due primarily to climate changes and sea level fluctuations (Suguio et al., 1985).

\section{Distribution, phylogenetic patterns, and the biogeography of the fish fauna from the Brazilian continental margin.}

\section{Distributional patterns}

The ichthyofauna of the coastal drainages of eastern Brazil is of great biogeographic significance. The main hydrographic systems (Paraguaçú, Contas, Jequitinhonha, Doce, Paraíba do Sul, Ribeira de Iguape, Itajaí and Jacuí) (Fig. 4), as well as several other smaller adjacent drainages, demonstrate a high degree of endemism. Of a total of 285 fish species listed by Bizerril (1994) for these basins, 95\% were considered endemic and with $23.4 \%$ of the genera endemic.

Interesting biogeographic patterns are exhibited by the freshwater ichthyofaunas on the Brazilian crystalline shield and the Atlantic coastal drainages. Potentially informative patterns are exhibited by deep phylogenetic lineages as well as closely related species groups occurring in coastal drainages and the adjacent upland crystalline shield rivers.

The phylogenetic scope of these patterns suggests that cladogenetic events between coastal drainages and the upland crystalline shield are ongoing over long stretches of time, and were in a sense repetitive, giving rise to similar sister-group phylogenetic patterns, which occurred in different time stages. These differences in the degree of inclusiveness between sister-groups probably reflect such sequence of continuous vicariance. In general, species-level patterns should be the most recent events whereas higher taxonomic group patterns are older.

In some cases, the degree of inclusiveness involve taxa which are the sister group of very large clades at familial or subfamilial levels (herein termed Pattern A) (Fig. 9) or in other cases, involving sister-group relationships between genera (Pattern B) (Fig. 10). These patterns, along with the specieslevel similarities between both areas (Pattern C) will be discussed separately. Unfortunately, due to the lack of phylogenetic information for many groups occurring in eastern Brazil, the patterns hypothesized herein are not supported by numerous examples, but these can be tested by future study. 


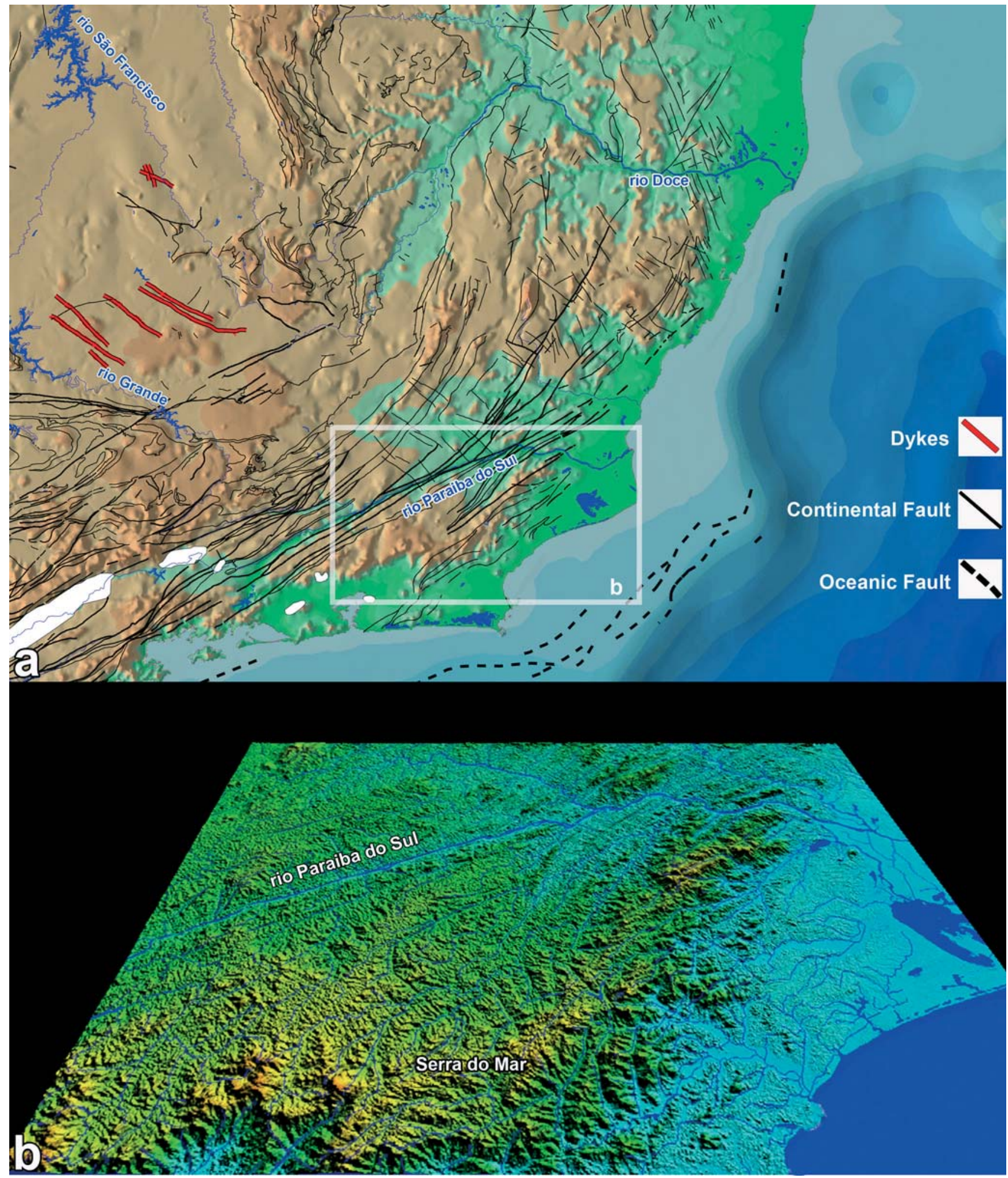

Fig. 7. (a) Map of northeastern segment of Southeastern Brazilian coast showing the complex system of Pre-Cambrian and Mesozoic continental rifts controlling drainage and topography. (b) Detail of the straight course of the rio Paraíba do Sul Rift Valley produced from a digital elevation model by radar interferometry (NASA, The Shuttle Radar Topography Mission). 


\section{Ancient events: Pattern A}

Stiassny \& Pinna (1994) noticed that taxa basal within their lineages are often notably depauperate in number of species when compared with their sister-groups, and frequently have extremely restricted geographical distributions. According to the same authors, this phenomenon is strikingly prevalent among freshwater fishes. Some coastal drainages of eastern Brazil are inhabited by taxa that are primary examples of such fact (Stiassny \& Pinna, 1994). This is designated herein as Pattern A.

Pattern A is exemplified by the Trichomycteridae catfishes of the subfamilies Trichogeninae (genus Trichogenes) and Copionodontinae (genera Glaphyropoma, and Copionodon). These catfishes are endemic to the small Atlantic tributaries between São Paulo and Rio de Janeiro (in the SE) and to the rio Paraguaçu basin (NE Brazil), respectively. Trichogeninae and Copionodontinae are probably sister-groups and together constitute the sister-group of the remaining members of the Trichomycteridae (Pinna, 1998) (Fig. 9a). The cladogenesis separating Copionodontinae and Trichogeninae catfishes from the remaining Trichomycteridae is, probably, of great antiquity. Trichomycterids excluding Copionodontinae and Trichogeninae underwent a long evolutionary history giving rise to more than 200 described species arranged in more then 42 genera, with widespread Trans/Cis-andean distributional ranges from Patagonia to Panama. Trichomycterids, in the course of their long evolutionary history, evolved a widerange of extreme ecological and morphological specializations including parasitic hematophagy (Pinna \& Wosiacki, 2003).

The doradid genus Wertheimeria (Siluriformes: Doradidae), endemic to the rio Jequitinhonha basin is, in turn, the sister group of the remaining doradids (Higuchi, 1992; Pinna, 1998) and was also mentioned by Stiassny \& Pinna (1994) as a primary example of a taxon basal to a much more diverse sister group. This case is herein considered another example of Pattern A (Fig. 9b). Similar to the example of trichomycterids, doradids underwent a long evolutionary history in Trans/Cis-Andean South America excepting for the Pacific Coast drainages, the Atlantic Coast south of rio de La Plata, and west of the rio Magdalena (Sabaj \& Ferraris, 2003). Doradids, as a consequence of their long evolutionary history, evolved in a wide range of forms, from diminutive species of $3.5 \mathrm{~cm}$ to larger forms of about $120 \mathrm{~cm}$ and $20 \mathrm{~kg}$ (Sabaj $\&$ Ferraris, 2003).

The conclusion taken from Pattern A is that the Brazilian eastern coastal rivers are still inhabited by reminiscent taxa of an ancient biogeographic history. It is proposed herein a Mesozoic (Cretaceous) age for the initial phase of diversification of an endemic ichthyofauna inhabiting the Brazilian coastal rivers that still occur today.

\section{Intermediate history: Pattern B}

This pattern is defined herein by sister-group relationships between the endemic ichthyofauna of the Brazilian coastal drainages and adjacent shield that includes intermediate degree of inclusiveness, in which, in some cases, both sister-clades underwent some subsequent radiation. The taxonomic resolution in these cases recognizes a phylogenetic interrelationship at the level of genera.

An example of Pattern B is the genus Scleromystax (Siluriformes: Callichthyidae: Aspidoradini), with four species that are endemic to the coastal drainages between the states of Espírito Santo and Santa Catarina (SE and S Brazil) which is the sister group of the more diversified genus Aspidoras (Britto, 2003) encompassing 18 species, widespread in both upland shield river and several coastal drainages (Reis, 2003) (Fig. 10a). A relatively antiquity for Callichthyidae is also corroborated by the fossil record. The unambiguous placement of the Argentinean fossil Corydoras revelatus in the Corydoradinae as confirmed by Britto (2003) indicates that the lineages leading to subfamily Corydoradinae occurred at least on the late Paleocene, as proposed by Reis (1998). Considering that Aspidoradini and Corydoradinae are sister-groups, this minimum age can be applied to both groups.

Another example of Pattern B is the genus Lignobrycon, with two known species, the extant $L$. myersi from rio do Braço (a coastal river of Bahia, NE Brazil) and the extinct L. ligniticus from the Tremembe formation (Oligocene-Early Miocene, São Paulo State, SE Brazil). Lignobrycon is hypothesized to be the sister group of the widespread Cis-Andean genus Triportheus (Malabarba, 1998) (Fig. 10b). In this example, a Tertiary minimum age based on the fossil record can also be inferred for Lignobrycon, a modern endemic component of the ichthyofauna of the Brazilian coastal drainages.

Armored catfishes of the Rhinelepis group (Armbruster, 1998) have similar phylogenetic and distributional patterns. Pogonopoma wertheimeri, from the rio Mucurí and São Mateus, and Pogonopoma parahybae, from the rio Paraíba do Sul, are sister-groups. Both species are considered to be the sister-group of $P$. obscurum, from the upper rio Uruguay (Quevedo \& Reis, 2002). The genus Pogonopoma, in turn, is hypothesized to be the sister group of the genus Rhinelepis (Armbruster, 1998; Quevedo \& Reis, 2002), which occurs in both Paraná and São Francisco basins in the crystalline shield, in the coastal rio Paraíba do Sul, and in Northeastern Brazil, but this latter occurrence was considered to be an introduction by Armbruster (1998) (Fig. 10c). Within Trichomycteridae this pattern is also recognized. The genus Microcambeva, with two species, M. barbata, described from the small coastal rio São João in the State of Rio de Janeiro, and M. ribeirae

Fig. 8. [next page] (a) Map of northeastern Brazil, at Borborema province, showing the complex system of Pre-Cambrian and Mesozoic continental rifts controlling drainage and topography. Taphrogenic basins (1 - rio Mamanguape and 2- Cariatá) became installed along the margin resulting from fault reactivations. b) Detail of the rio Mamanguape (1) and Cariatá (2) grabens produced from a digital elevation model by radar interferometry (NASA, The Shuttle Radar Topography Mission) (sources: Hearn et al., 2000; Bizzi et al., 2001; Brito Neves et al., 2004). 

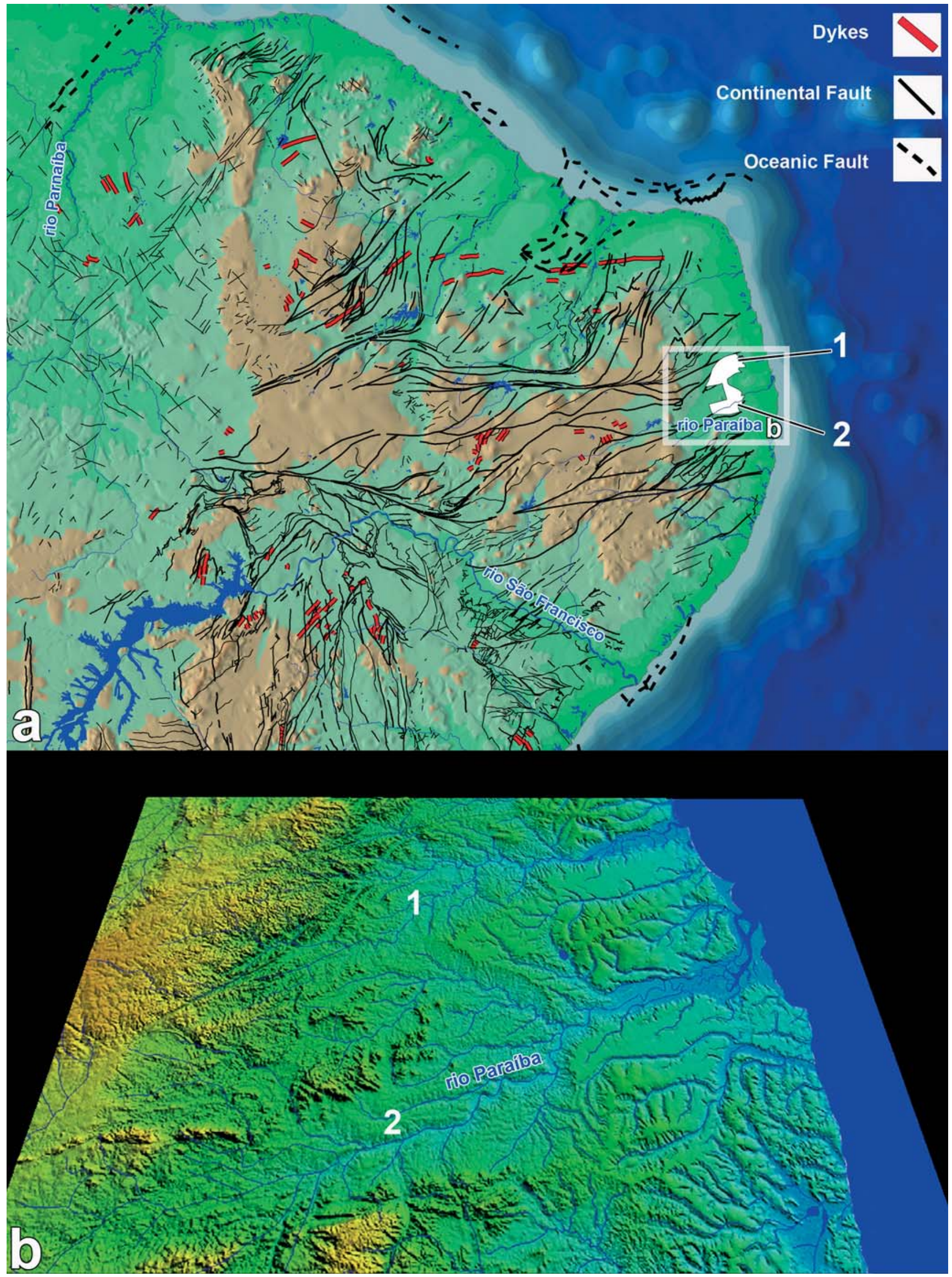

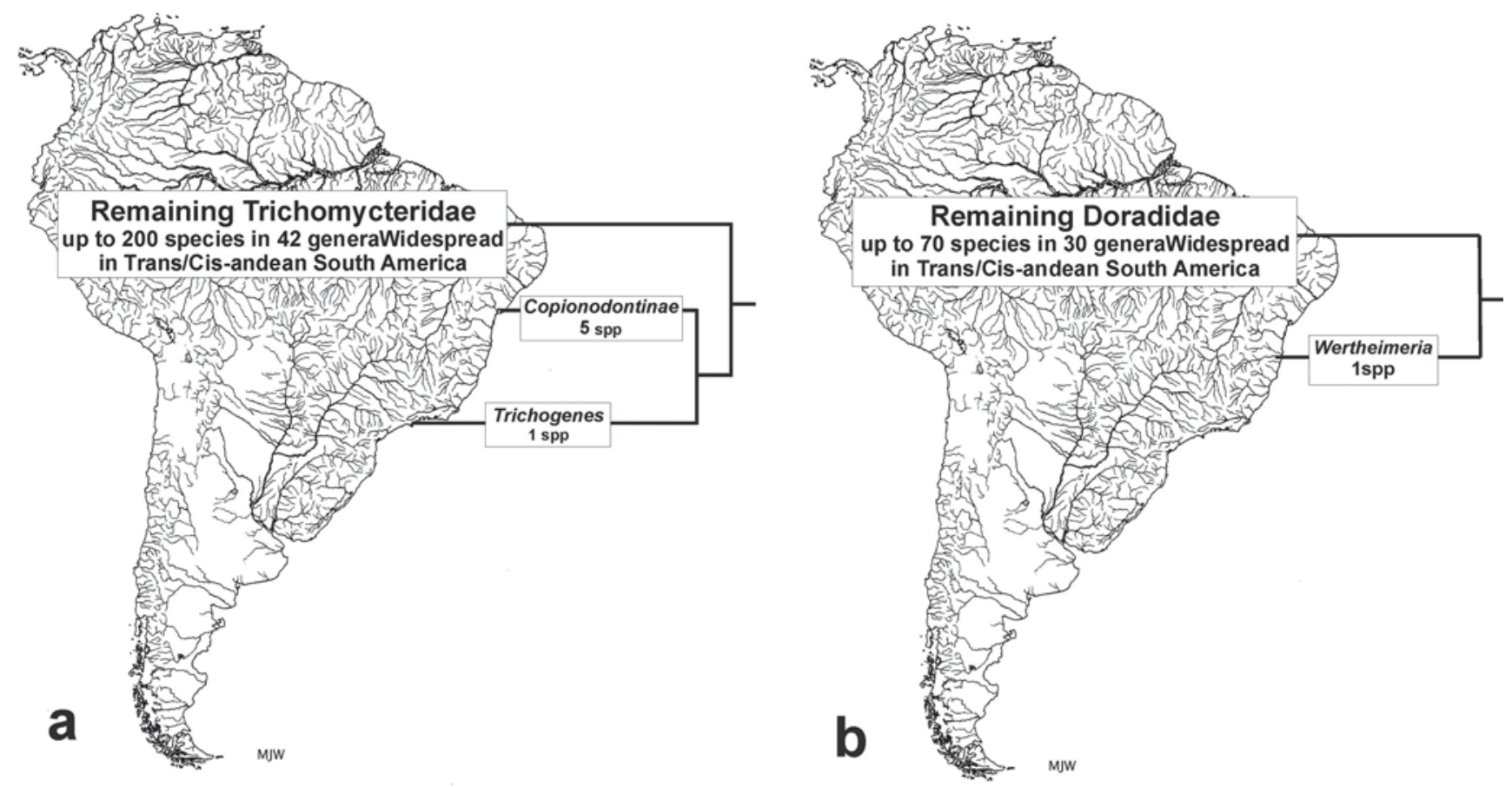

Fig. 9. Cladograms of taxa and areas showing the sister-group relationships included in Pattern A. a) Catfishes of the family Trichomycteridae. b) Catfishes of the family Doradidae. The degree of inclusiveness of this pattern suggests the most ancient cladogenetic event that is still recognized in respect to the ichthyofauna of the Brazilian coastal rivers.

(Costa et al., 2004), from the Ribeira de Iguape, both in southeastern Brazil. The genus Microcambeva was hypothesized by Costa \& Bockmann (1994) to be the sister-group of a more inclusive clade: the monotypic genera Malacoglanis from río Caquetá, Colombia plus Sarcoglanis, from the Amazonian rio Negro basin (Fig. 10d).

Some other elements of the endemic fish fauna from the coastal drainages of eastern Brazil can be also included in Pattern B, but these groups underwent major diversification in coastal drainages, while their sister-groups are found in the Brazilian crystalline shield and are depauperate in number of species. Primary examples in the Characidae are the members of the subfamily Glandulocaudinae, tribe Glandulocaudini. The species of the Mimagoniates are diversified (six species) and widespread along the coastal drainages, but their sister-group, the genus Glandulocauda (two species), which is primitive in several features, is endemic to the crystalline shield of southeastern Brazil, from the upper rio Tietê and upper rio Iguaçu (Weitzman et al., 1988; Weitzman \& Menezes, 1998). The sequential sister-group to both genera is the monotypic genus Lophiobrycon, which is also endemic to the southeastern crystalline shield, from the middle rio Grande (Castro et al., 2003) (Fig. 10e).

Weitzman \& Malabarba (1999), reviewing the genus Spintherobolus (Characiformes: Cheirodontine), comment that the distribution of this genus remains something of an enigma. This genus, however, is a typical representative of pattern B, with three species (S. broccae, S. leptoura, and $S$. ankoseion) distributed along the coastal rivers between the
Baia de Guanabara in the State of Rio de Janeiro to the northern coast of the State of Santa Catarina. These species form a clade, which is the sister-group of S. papilliferus, known only from the headwaters of the upland rio Tietê (Fig. 10f) (Weitzman \& Malabarba, 1998).

The degree of inclusiveness in this pattern is suggestive of an intermediate stage between Pattern A and the following pattern $\mathrm{C}$, related to species-level similarities between both areas. The occurrence, within representatives of Pattern B, of dated fossil species corroborate that cladogenetic event within this pattern probably occurred at least by the Tertiary.

\section{The most recent interchanges: Pattern C}

This pattern reflects the most recent vicariant events between the upland crystalline shield rivers and the adjacent coastal drainages that lead to the recognition of shared species between than, and in some cases, of truly hybrid zones.

Fig. 10. [next page] Cladograms of taxa and areas showing the sister-group relationships included in Pattern B. a) Catfishes of the tribe Aspidoradini (Calichthyidae). b) Characins of the genera Lignobrycon and Triportheus. c) Armored catfishes of the Rhinelepis group. d) Catfishes of the subfamily Sarcoglanidinae. e) Characins of the tribe Glandulocaudini. f) Characins of the subfamily Cheirodontinae, genus Spintheropolus. These are probably intermediate events that took place along the Tertiary, as concluded by the fossil records of some taxa included in this pattern. 

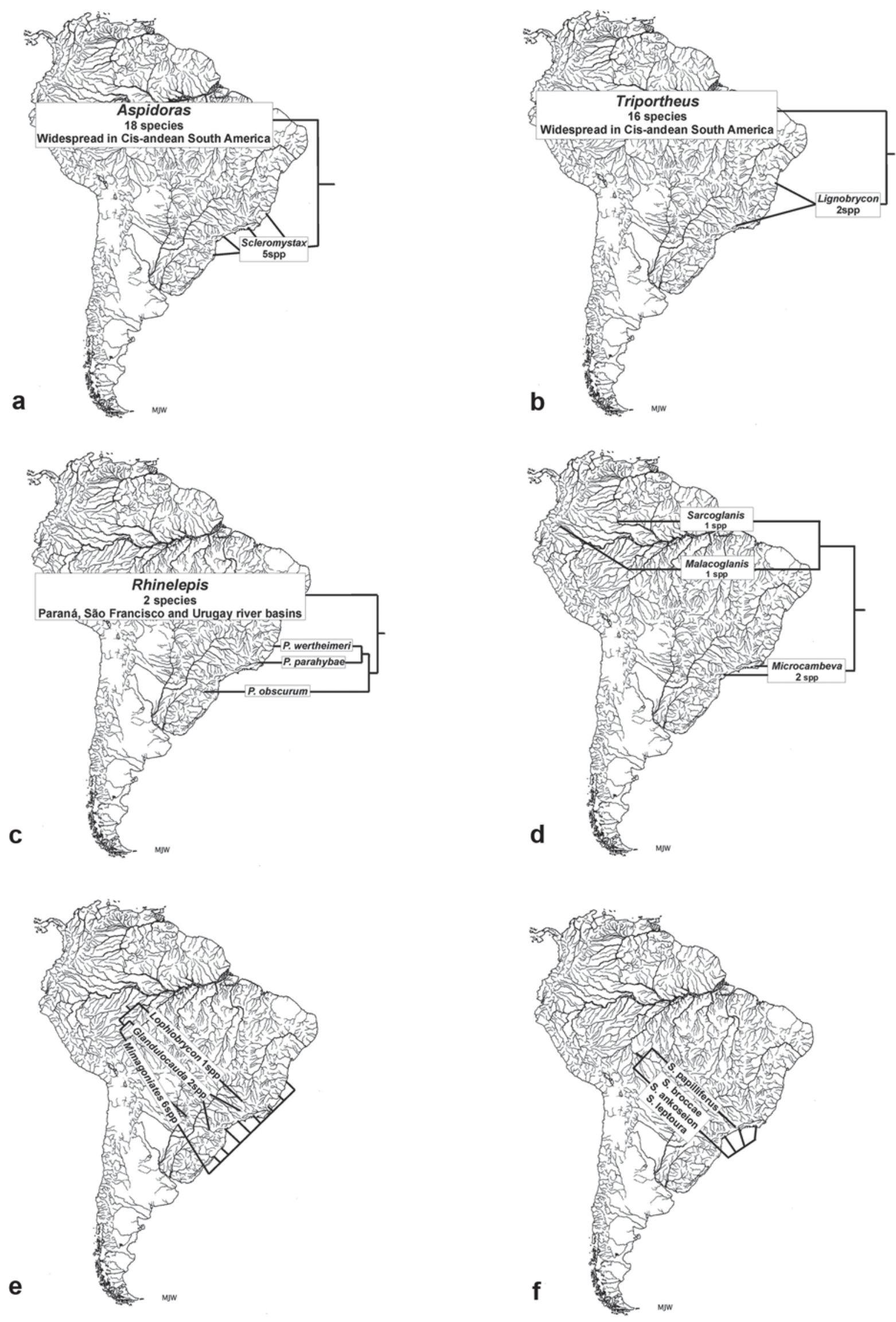
The frequency of shared species between the coastal drainages and the upland adjacent Paraná and São Francisco basins was estimated by Bizerril (1994) in 17 and 11\%, respectively. Since then, revisionary papers of several groups promote changes in these percentiles. Several species were revealed to be "species complexes" whereas others were synonymized. Examples taken from recent revisionary papers, however, illustrate Pattern C.

In southern Brazil, several species are shared between the isolated coastal drainages and the adjacent upland. Lucinda (2005), showed that Cnesterodon decemmaculatus (Cyprinodontiformes: Poeciliidae: Poeciliine) is widespread in the lower rio Uruguay and Jacuí in the State of Rio Grande do Sul, Brazil, río Negro and Salado in Argentina as well as in small coastal drainages of Uruguay and Argentina. Cnesterodon brevirostratus also occur in the upper rio Uruguay, rio Jacuí and other coastal drainages (Lucinda, 2005). Similar distributional patters in the southernmost coast of Brazil and neighboring areas were given by Silva (2004) who described Bryconamericus patriciae and reported its occurrence in both upper Uruguay and the coastal rio Jacuí. Reis et al. (1990), revising the armored catfishes of the genus Hypostomus (Siluriformes: Loricariidae) from southern Brazil demonstrate the same fact: Hypostomus commersonii and $H$. aspilogaster occur in rio Uruguay, rio Jacuí and other tributaries of the coastal laguna dos Patos system.

Also in southeastern Brazil, areas can be identified in which Pattern C occurs: 1) the upper rio Tietê, and 2) the area including the headwaters of the coastal rio Ribeira de Iguape and the adjacent upland tributaries of the Paraná basin, the Iguaçu and Paranapanema rivers. However, in these cases, the shared components are taxa, otherwise, endemic to the coastal drainages, in which they are somewhat widespread. This phenomenon suggests that the upper rio Tietê suffered a posterior input of an ichythyofauna once found only in coastal rivers where they were, prior to these cladogenetic events, endemic. Langeani (1989) for the first time identified shared species between the upper Tietê and adjacent coastal drainages. In the case of the upper rio Tietê, the fish fauna includes several species such as Hollandichthys multifasciatus, Pseudocorynopoma heterandria, Hyphessobrycon bifasciatus, Hyphessobrycon reticulatus, and Gymnotus pantherinus (Langeani, 1989; Quevedo \& Reis, 2002), otherwise, only found in the coastal rivers. In the upper rio Iguaçu, this phenomenon can be also identified by the presence of Mimagoniates microleps. This species is otherwise, found only in coastal drainages and the available phylogenetic information demonstrated that this species arose from a common ancentor that was endemic to the coastal rivers (Weitzman et. al., 1988). Other typical representatives of the ichthyofauna of the coastal drainages recently recorded in the upper Iguaçu are Hyphessobrycon griemi, H. bifasciatus, and $H$. reticulatus (Ingenito et al., 2004).

Some other elements of the upper rio Iguaçu fish fauna are also reported in the neighboring Ribeira de Iguape and Paranapanema rivers, such as Trichomycterus davisi
(Suluriformes: Trichomycteridae) (Ingenito et al., 2004) and Hypostomus ancistroides (Suluriformes: Loricariidae) (Oyakawa et al., 2005). Bizerrill \& Lima (2000) also mentioned that Rhamdiopsis moreirai (Siluriformes: Heptapteridae) is shared between the upper Ribeira de Iguape and Iguaçu.

In the northeastern margin of the Paraná basin, adjacent to the upper rio São Francisco, Paraíba do Sul, and the adjacent coastal drainages south of the mouth of rio Doce, some species also become widespread. This is the case of the species of Piabina (Characiformes: Characidae). Piabina argentea is widespread through the upper Paraná basin, São Francisco, and in some coastal rivers of the Atlantic slope: the Itapicurú, Paraíba do Sul, and Itapemirim river basins (Vari \& Harold, 2001). Piabina is hypothesized to be the sistergroup of Creagrutus, with Trans-Andean distribution. Recently, the most basal species of Creagrutus was described and it is endemic to the uppermost portions of the rio Paraná in central Brazil (Ribeiro et al., 2004). The available phylogenetic hypothesis of Piabina and Creagrutus suggests that the Brazilian crystalline shield, probably the Paraná basin, is the place for the initial diversification of the group. This suggests that Piabina argentea became widespread into coastal rives secondarily.

In the northeastern portion of the Brazilian coast, the faunal interchange between adjacent basins was also reported, reflecting a mixed ichthyofauna. Rosa et al. (2004) concluded that the ichthyofauna from the Caatinga semi-arid biome of northeastern Brazil, encompassing portions of the São Francisco, Parnaíba and several other adjacent coastal rivers basins, are hybrid. These authors registered that some species are widespread in two or more basins encompassed by the Caatinga semi-arid vegetation biome. This is the case, for example, of Triportheus signatus (Characiformes: Characidae), Prochilodus brevis (Characiformes: Prochilodontidae), and Cichlasoma orientale (Perciformes: Ciclidae) which are endemic to more than one basin encompassed by the Caatinga semi-arid biome. This ichthyofauna is also composed of much more widespread species, such as Parauchenipterus galeatus (Siluriformes: Auchenipteridae) found in all basins encompassed by the Caatinga.

The concluding remarks regarding Pattern $\mathrm{C}$ is that the faunal interchange between upland rivers and coastal drainages and vice-versa occurred along the whole divergent continental margin of Brazil. Speciation, however, was not followed by cladogenetic events of Pattern $\mathrm{C}$, suggesting its recent age relatively to the previously discussed patterns (A and $\mathrm{B}$ ). The relatively recent faunal interchange between isolated hydrographic basins indicated by Pattern $\mathrm{C}$ needs an explanative model, which will be proposed in the following section.

\section{Biogeographic history}

Synchronization of biological and geological processes is a primary tenet of historical biogeography. Two approaches are possible for this: the study of pattern or processes in evolution. Herein, synchronization is hypothesized to occur 

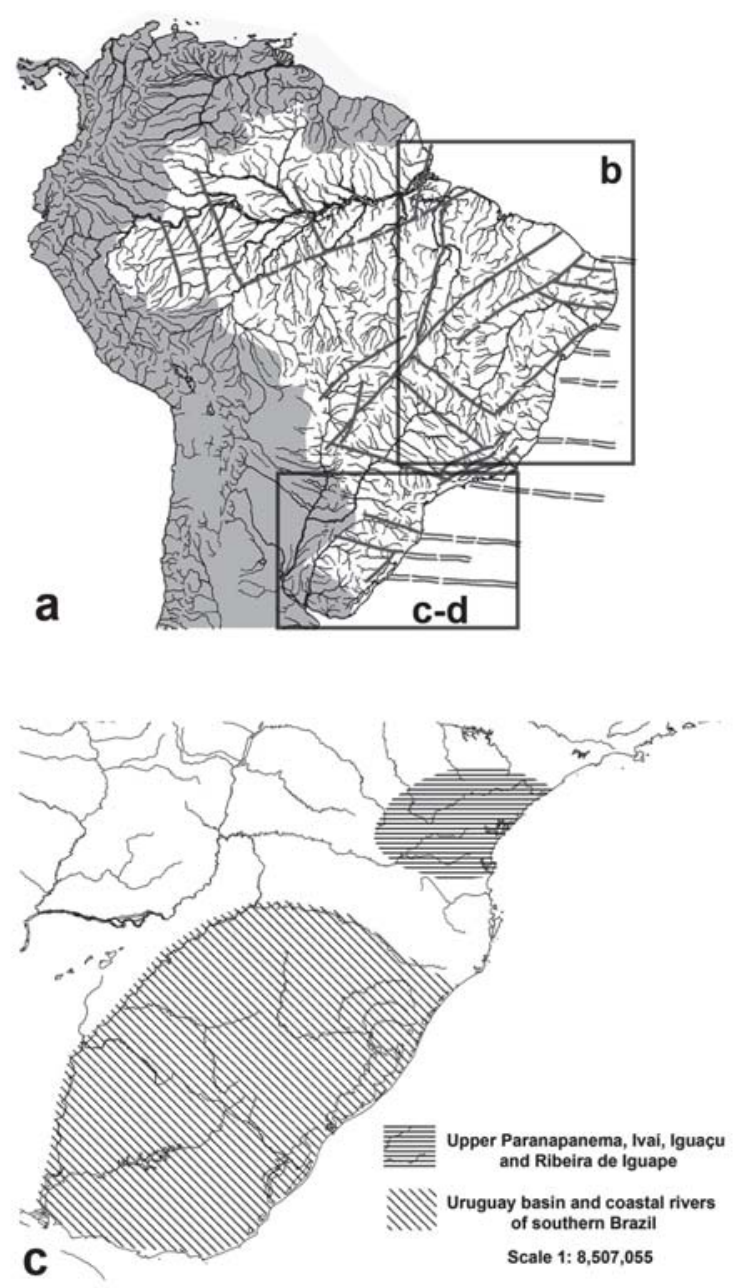
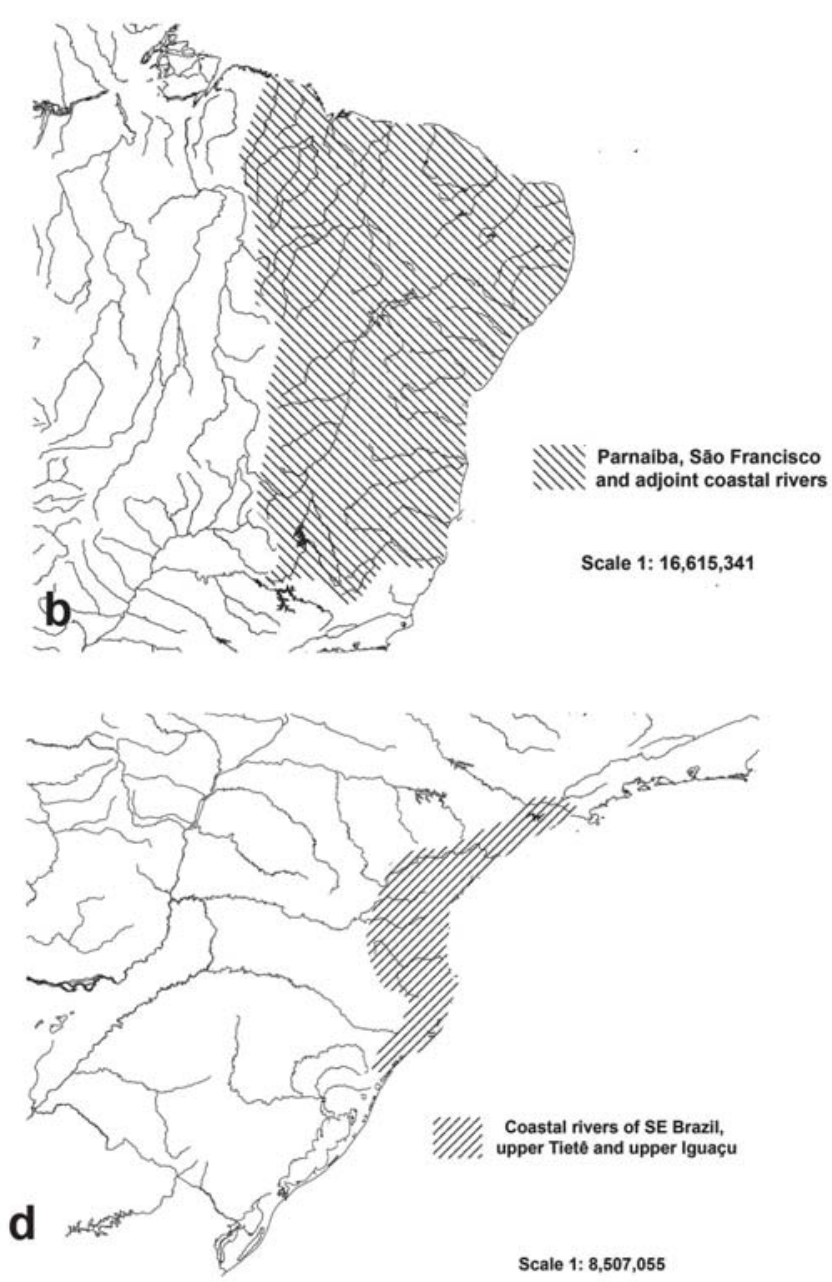

Fig. 11. (a) The main axes of Quaternary tectonics in Brazil (gray lines) (according to Saadi, 1993) and areas of coincident distributional rages of several species in both isolated coastal rivers and adjacent drainages. (b) The northeastern margin of Brazil, including the Parnaíba, São Francisco and adjacent coastal rivers (c) The Southern most Brazil, encompassing the Uruguay and surroundings coastal rivers as well as the headwaters of the Paranapanema, Ivaí, Iguacú and Ribeira de Iguape. (d) The area encompassed by the CRSB, in southeastern Brazil, including the coastal rivers and the adjacent upper Tietê and upper Iguaçu.

based on the "Pattern" approach. Repetitive distributional and phylogenetic patterns, rather than previous knowledge about speciation rates or other evolutionary processes, underpin our interpretation of the biogeographic history.

The presence, in the coastal drainages of eastern Brazil, of an ancient fish fauna which is the sister group of much more inclusive, derived and widespread taxa (Pattern A), supports the hypothesis that initial cladogenetic events were related to the origin of the first drainages that flowed into the Atlantic Ocean. These rivers were probably structurally oriented by megadomes, together with drainages that were structurally oriented by large faults and grabens. This is the case with all of the Atlantic tributaries north of the Mantiqueira-Angola and south of NE Brazil-Niger megadomes, where complex fault systems were, in some cases, responsible for the structure of the drainage pattern (Saadi et al., 2002).
Pattern B suggests the continued faunal interchange between the upland crystalline shield and coastal rivers throughout the Tertiary (Paleogene and Neogene). The continued erosive retreat of the eastern margin of the platform, for example in southeastern Brazil along the margins of the Serra do Mar escarpments, was responsible for transferring additional ancestral stocks from upland to lowland river systems, with such groups undergoing subsequent diversification in both upland and coastal drainages. An example of this process was the erosive opening of the Ribeira de Iguape basin along the Pre-Cambrian shear zone that governs the plan of this river. These generalized erosion were concomitant to the reactivations of the ancient system of Pre-Cambrian and Mesozoic rifts present along the whole tectonic active Brazilian continental margin.

Vertical movements between large rifted blocks resulting from such reactivations were also of great importance in the 
development of the present distribution patterns of the fish fauna, which is especially evident in the rifted margin of southeastern Brazil. The Taubaté basin clearly exemplifies how the capture of hydrographic systems by large grabens, capturing not only headwaters but also larger rivers from adjacent upland areas, is a significant factor in determining the distribution patterns of the aquatic biota. The fossil fish fauna of the Tremembé Formation contains representatives of the surrounding basins, including some fishes typical of large rivers such as the siluriform Steindachneridion (also found in the Jequitinhonha, Doce, Paraíba do Sul and upper Uruguay river systems), and exemplifies the degree of faunal exchange that resulted from such tectonic phenomena. Unfortunately, the Taubaté basin is the only basin of the taphrogenic system encompassed by the Continental Rift of Southeastern Brazil that is known to contain fossil fishes.

The geological mechanisms associated with Pattern $\mathrm{C}$ takes us to the fascinating paradigms associated to the concepts of Neotectonics. According to recent models, the widespread system of rifts and other crustal discontinuities present along the Atlantic divergent margin of South America act as weakness zones more prone to tectonic activity and deformations (Saadi, 1993; Saadi et al., 2002). Several hydrological anomalies are symptomatic of active tectonics (Moores \& Twiss, 2000), along which, for our aims, the most important are stream captures (Cobbold et al., 2001). Stream capture or piracy can operate basically in two different ways in tectonic active areas. It can be a direct effect of tectonic stress, when the streams suffer an abrupt deviation as a consequence of the relative movement between rifted blocks. Alternatively, it occurs by differential erosion, because deformation in the landscape promote the adjustment of the drainage to new base level, causing streams on lowered blocks, with a steeper gradient and, consequently more energy, to extends its valley headward due to erosion, eventually breaking down the divide and capturing part or all of the drainage of adjacent slower streams (Tarbuck \& Lutgens, 2002). The continuity of these processes was probably the cause of an intense faunal input from the crystalline shield fauna into the coastal rivers along the Tertiary and afterwards, as exemplified by Patterns $\mathrm{B}$ and $\mathrm{C}$.

With no exceptions, the above mentioned areas in which Pattern $\mathrm{C}$ occurs have been identified as active tectonic areas, some of these with proven activity younger than 1.6 Ma (Saadi et al., 2002) (Fig. 11). This is especially true for, at least, two areas on the upland crystalline shield of southeastern Brazil, which share a mixed fish fauna with the lowland coastal drainages. These are: 1) the area including the headwaters of the rio Ribeira de Iguape, Iguaçu and Paranapanema rivers, and 2) the upper portion of the rio Tietê. Not surprisingly, these regions correspond to areas with interesting geological characteristics. In both cases, a complex system of fault lineaments and rifted blocks imposed an especially accelerated fluvial dynamism.

In the region of Paranapanema, Iguaçú and Ribeira de Iguape headwaters, the most prominent geological feature is the Ponta Grossa Arch. The arch consists of an uplift of the crystalline basement along the southeastern portion of the Paraná Basin (Petri \& Fulfaro, 1983). The Ponta Grossa Arch is easily visible on geological maps due to the westward curvature of the southeastern Paraná Basin (Raposo, 1995) displaying an intricate systems of deep faults and fractures. The main faults of the Ponta Grossa Arch are those present in the Guapiara, São Jerônimo-Curiúva and Rio Alonzo structural fault lineaments (Raposo, 1995). This fault system was supposed to be the main conduit of the immense Cretaceous flow of lava over the Paraná Basin know as Serra Geral Formation, which left a large system of dykes of intrusive magma showed in Fig. 6a. Some authors have pointed out that the Ponta Grossa Arch has a general tendency to uplift (Almeida \& Carneiro, 1998) and underwent tectonic activity during the Cenozoic (Almeida \& Carneiro, 1998; Souza \& Souza, 2002). The tectonic activity of the Ponta Grossa Arch could have resulted in a particularly accelerated fluvial dynamism between adjacent drainage systems, accelerating the faunal exchange between them. In the Ponta Grossa Arch, faults control the relief and the drainage patterns (Melo, 2002). Vertical movements between faulted blocks and erosive evolution of rivers along such rifts promote mixing between adjacent drainages, and likely explain the faunal exchanges that occurred between the coastal Ribeira de Iguape, and the uplands Iguaçu and Paranapanema rivers.

Similar process might have occurred in the upper Tietê. In its upper portion, this river drains the São Paulo Basin, which was, apparently, an extension of the Taubaté Basin during the initial phase of the taphrogenic event that originated both basins (Ab’Sáber, 1998; Riccomini, 1989; Riccomini et al., 2004). Disconnection of these basins was caused by subsequent tectonic event in the tectonic history of the CRSB. The same tectonic uplift could be responsible for sending back to the upper Paraná Basin an aquatic biota that was once associated to lowland costal drainages during an intermediate tectonic and erosive phase. In fact, the idea that southeastern Brazil is a tectonically active area and prone to undergo deformations (Cobbold et al., 2001) is strongly supported by these complex distributional patterns included in Pattern C. The intense tectonic activity along the CRSB also explain why the Paraná basin contributed more (in terms of ancestral stocks) to the development of the coastal drainages fish fauna, as mentioned by Bizerril (1994).

The same is true for the northeastern Brazil, in the Borborema Province. That region is extensively transected by such kind of structural discontinuities: Pre-Cambrian rifts and shear zones as well as several branches of oceanic rift zones that extends over the northeastern margin of the continent and are all prone do undergo deformations (Saadi, 1993) (Fig. 11). The neotectonic behavior of the Borborema Province should result in an accelerated fluvial dynamism between adjacent drainages resulting in extensive faunal interchange. The identification of such phenomenon in this region made by Brito Neves et al. (2004) that resulted in the deviation of the rio Paraíba in the Tertiary corroborates this idea. 
The tectonic control over the distributional pattern of the ichthyofauna from the coastal drainages and adjacent upland rivers seems to be the rule. A more detailed view of this process that will probably occur in the future should confirm this idea and provide more detailed causal explanations for other areas that become not exemplified or discussed herein. It is intriguing that Pattern $\mathrm{C}$ is recurrent along the whole area encompassed by the rifted eastern continental margin of South America, suggesting a high degree of faunal interchange between adjacent basins.

The mixed nature of hydrografic basins was already noticed by Costa (2001) who proposed that headwaters are typically areas of complex faunal interchange between adjacent regions rather than repeating components of the faunal stocks of a major unit represented by the basin as a whole, but no explanatory model was provide for that fact. Figure 11a shows that the same kind of structural discontinuities found along the eastern margin of Brazil have a much more including extension. The same tectonic mechanisms allowing interchanges between the Brazilian coastal rivers with neighboring drainages probably also took place between basins located into the continent interior at the crystalline shield. These interchanges caused by stream captures were supposedly to occur where divides are transected by crustal discontinuities, such as Pre-Cambrian rifted and shear zones or extensions of the oceanic rifted zones over the continents (Saadi, 1993).

The above arguments run counter to theories that propose that diversification of the fish fauna of the coastal drainages of South America was exclusively related to sea level changes during the Late Pleistocene (Weitzman et al., 1988). That model hypothesized that, when the sea level was about $100 \mathrm{~m}$ lower than today, the fish fauna was able to become more widespread. Following a rise in sea level, speciation occurred within isolated river basins. This model, however, does not explain the mechanism by which species from coastal rivers, supposedly originated during the late Pleistocene, could occur secondarily in upland rivers, such as the upper Tietê and Iguaçu. The erosive retreat of the eastern margin of southeastern Brazil can continuously introduce ancestral stocks from upland rivers into coastal drainages, but not in the opposite way. Only significant tectonic deformations are able to send back to the upland, species typical to coastal rivers found in the upper portion of the Tietê and Iguaçu basins. If the explanation of pattern $\mathrm{C}$ is associated with tectonic relationships, than the fish fauna involved had to have evolved prior to the sea level changes of the Late Pleistocene, a period when the South American Platform underwent no expressive vertical movements between faulted blocks and the present shape of the eastern continental margin was established. The sea level changes of the Late Pleistocene can explain the widespread distributional ranges of several taxa only along the coastal drainages, but fails to explain the occurrence in upland basins of some species that arose from a common ancestor that was endemic to the lowland coastal rivers. The major tectonic influence on distribution patterns and cladogenetic events between the eastern coastal drain- ages and the upland crystalline shield predicts that they took place during a much longer period of time, from the end of the Cretaceous to the early Quaternary.

\section{Acknowledgements}

This paper was greatly improved by the suggestions, criticisms and detailed review of Richard Vari (NMNH, Smithsonian Institution), Marcelo Carvalho (FFCLRP-USP) and Claudio Riccomini (IG-USP). Naércio Menezes (MZUSP), Francisco Langeani (IBILCE, UNESP), Flávio Bockmann (FFCLRPUSP), Dalton Amorin, Flávio Lima (MZUSP), and Ricardo Castro (FFCLRP-USP) provided useful comments concerning its contents. John Lundberg (ANSP), Dilce Rossetti (INPE) and a third anonymous referee provide important suggestions over the manuscript. The author is financially supported by the Conselho Nacional de Desenvolvimento Científico e Tecnológico (CNPq, grant No.140488/04-9).

\section{Literature Cited}

Ab'Saber, A. N. 1957. O problema das conexões antigas e da separação da drenagem do Paraiba e Tietê. Boletim Paulista de Geografia, 26: 38-49.

Ab'Saber, A. N. 1998. Megageomorfologia do Território Brasileiro. Pp. 71-106. In: Cunha, S. B. \& A. J. T. Guerra (Eds.). Geomorfologia do Brasil. Rio de Janeiro, Bertrand, 388p.

Almeida, F. F. M. 1967. Origem e evolução da plataforma brasileira. Boletim da Divisão de Geologia e Mineralogia, Departamento Nacional da Produção Mineral, 241: 1-36.

Almeida, F. F. M. 1976. The system of continental rifts bordering the Santos Basin, Brazil. Anais da Academia Brasileira de Ciências, 48(supplement): 15-26.

Almeida, F. F. M., B. B. Brito Neves \& C. D. R. Carneiro. 2000. The origin and evolution of the South American Platform. EarthScience Reviews, 50(2000): 77-111.

Almeida, F. F. M. \& C. D. R. Carneiro. 1998. Origem e evolução da Serra do Mar. Revista Brasileira de Geociências, 28(2): 135-150.

Almeida, F. F. M., C. D. R. Carneiro \& A. M. P. Mizusaki. 1996. Correlação do magmatismo das bacias da margem continental brasileira com o das áreas emersas adjacentes. Revista Brasileira de Geociências, 26(3): 125-138.

Almeida, F. F. M., Y. Hasui, B. B. Brito Neves \& R. A. Fuck.1981. Brazilian structural provinces: an introduction. Earth-Science Reviews, 17(1-2): 1-29.

Armbruster, J. W. 1998. Phylogenetic relationships of the suckermouth armored catfishes of the Rhinelepis group (Loricariidae: Hypostominae). Copeia, 1998: 620-636.

Bizerril, C. R. S. F. 1994. Análise taxonômica e biogeográfica da ictiofauna de água doce do leste brasileiro. Acta Biologica Leopoldensia, 16(1): 51-80.

Bizerril, C. R. S. F. \& N. R. W. Lima. 2000. Levantamento da ictiofauna da bacia do rio Ribeira de Iguape, Brasil. Acta Biologica Leopoldensia, 22(1): 103-110.

Bizzi, L. A., C. Schobbenhaus, J. H.Gonçalves, F. J. Baars, I. M. Delgado, M. B. Abram, R. L. Neto, G. M. M. Matos \& J. O. S. Santos. 2001. Geology, tectonics and mineral resources of Brazil: Geographic information system (GIS) and maps at the 1:2500000 scale. CPRM, Brasília, 4 CD-Rom. ISBN: 85-7499006-X. 
Brito-Neves, B. B., C. Riccomini, T. M. G. Fernandes \& L. G. Sant'Anna. 2004. O sistema tafrogênico Terciário do saliente oriental nordestino na Paraíba: um legado Proterozóico. Revista Brasileira de Geociências, 34(1): 127-134.

Britto, M. R. 2003. Phylogeny of the subfamily Corydoradinae Hoedeman, 1952 (Siluriformes: Callichthyidae), with a definition of its genera. Proceeding of the Academy of Natural Sciences of Philadelphia, 153(1): 119-154.

Castro, R. M. C., A. C. Ribeiro, R. C. Benine \& A. L. A. Melo. 2003. Lophiobrycon weitzmani, a new genus and species of glandulocaudine fish (Characiformes: Characidae) from the rio Grande drainage, upper rio Paraná system, southeastern Brazil. Neotropical Ichthyology, 1(1): 11-20.

Cesero, P. \& F. C. Ponte.1997. Análise comparativa da paleogeologia dos litorais atlânticos brasileiro e africano. Boletim de Geociências, PETROBRAS, 11(1/2): 1-18.

Cobbold, P. R., K. E. Meisling \& V. S. Mount. 2001. Reactivation of an obliquely rifted margin, Campos and Santos basins, southeastern Brazil. The American Association of Petroleum Geologists Bulletin, 85(11): 1925-1944.

Cordani, U. G. \& K. Sato.1999. Crustal evolution of the South American Platform, based on $\mathrm{Nd}$ isotopic systematics on granitoid rocks. Episodes, 22(3): 167-173.

Cordani, U. G., K. Sato, W. Teixeira, C. C. G. Tassinari \& M. A. S. Basei. 2000. Crustal evolution of the South American Platform. Pp. 19-40. In: Cordani, U. G., E. J. Milani, A. Thomaz-Filho \& D. A. Campos (Eds). Tectonic evolution of South America. $31^{\text {st }}$ International Geological Congress. Rio de Janeiro, Academia Brasileira de Ciências, e Departamento Nacional da Produção Mineral (DNPM), 856p.

Costa, W. J. E. M. 2001. The Neotropical annual fish genus Cynolebias (Cyprinodontiformes:Rivulidae): phylogenetic relationships, taxonomic revision and biogeography. Ichthyological Exploration of Freshwaters, 12(4): 333-383.

Costa, W. J. E. M. \& F. A. Bockmann. 1994. A new genus and species of Sarcoglanidinae (Siluriformes: Trichomycteridae) from southeastern Brazil, with a re-examination of subfamilial phylogeny. Journal of Natural History, 28(3): 715-730.

Costa, W. J. E. M., S. M. Q. Lima \& C. R. S. F. Bizerril. 2004. Microcambeva ribeirae sp.n. (Teleostei: Siluriformes: Trichomycteridae): a new sarcoglanidine catfish from the Rio Ribeira do Iguape basin, southeastern Brazil. Zootaxa, 563: 1-10

Cox, K. G. 1989. The role of mantle plumes in the development of continental drainage patterns. Nature, 342: 873-876.

Da Rosa, Á. A. S. \& A. J. V. Garcia. 2000. Paleobiogeographic aspects of northeast Brazilian basins during the Berriasian before the break up of Gondwana. Cretaceous Research, 21: 221-339.

Ernesto, M., L. S. Marques, E. M. Piccirillo, E. C. Molina, N. Ussami, P. Comin-Chiaramonti \& G. Bellieni. 2002. Paraná Magmatic Province-Tristan da Cunha plume system: fixed versus mobile plume, petrogenetic considerations and alternative heat sources. Journal of Volcanology and Geothermal Research, 118: 15-36.

Gallagher, K., C. J. Hawkesworth \& M. S. M.Mantovani.1994. The denudation history of the onshore continental margin of SE Brazil inferred from apatite fission track data. Journal of Geophysical Research, 99: 18117-18145.

Hearn, P. Jr., T. Here, P. Schruben, D. Sherrill, C. LaMar \& P. Tsushima. 2000. Global GIS database: Digital atlas of Central and South America. U.S. Geological Survey, Digital Data Series DDS-62-A.

Higuchi, H. 1992. A phylogeny of the South American thorny catfishes (Osteichthyes; Siluriformes, Doradidae). Unpublished
Ph.D. Dissertation, Harvard University, Cambridge. 372p.

Ingenito, L. F. S., L. F. Duboc \& V. Abilhoa. 2004. Contribuição ao conhecimento da ictiofauna do alto rio Iguaçu, Paraná, Brasil. Arquivos de ciências veterinárias e zoologia da UNIPAR, 7(1): 23-36.

Langeani, F. 1989. Ictiofauna do alto curso do rio Tietê (SP): taxonomia. Unpublished M.Sc. Thesis. Universidade de São Paulo. São Paulo, 231p

Lucinda, P. H. F. 2005. Systematics of the genus Cnesterodon Garman, 1895 (Cyprinodontiformes: Poecilidae: Poeciliinae). Neotropical Ichthyology, 3(2): 259-270.

Lundberg, J. G., L. G. Marshall, J. Guerrero, B. Horton, M. C. S. L. Malabarba \& F. Wesselingh. 1998. The stage for Neotropical fish diversification: A history of tropical South American rivers. Pp 13-48. In: Malabarba, L. R., R. E. Reis, R. P. Vari, Z. M. S. Lucena \& C. A. S. Lucena (Eds.). Phylogeny and classification of Neotropical fishes. Porto Alegre, Edipucrs, 603p.

Malabarba, M. C. S. L. 1998. Phylogeny of fossil Characiformes and paleobiogeography of the Tremembé formation, São Paulo, Brazil. Pp. 69-84. In: Malabarba, L. R., R. E. Reis, R. P. Vari, Z. M. S. Lucena \& C. A. S. Lucena (Eds.). Phylogeny and classification of Neotropical fishes. Porto Alegre, Edipucrs, 603p.

Melo, M. S. 2002. Canyon do Guartelá, PR: profunda garganta fluvial com notáveis exposições de arenitos devonianos. Pp. 279-288. In: Schobbenhaus, C., D. A. Campos, E. T. Queiroz, M. Winge \& M. L. C. Berbert-Born (Eds.). Sítios Geológicos e Palelontológicos do Brasil. Brasília. Departamento Nacional de Produção Mineral (DNPM), 540p.

Milani, E. J. \& A. Thomaz-Filho. 2000. Sedimentary basins of South America. Pp. 389-449. In: Cordani, U. G., E. J. Milani, A. Thomaz-Filho \& D. A. Campos (Eds). Tectonic evolution of South America. 31st International Geological Congress. Rio de Janeiro, Academia Brasileira de Ciências e Departamento Nacional da Produção Mineral (DNPM), 856p.

Modenesi-Gauttieri, M. C., S. T. Hiruma \& C. Riccomini. 2002. Morphotectonics of a high plateau on the northwestern flank of the Continental Rift of Southeastern Brazil. Geomorphology, 43: $257-271$.

Mohriak, W. U. \& A. Z. N. Barros. 1990. Novas evidências de tectonismo Cenozóico na região sudeste do Brasil: o graben de Barra de São João na plataforma de Cabo Frio, RJ. Revista Brasileira de Geociências, 20(1-4): 187-196.

Moores, E. M. \& R. J. Twiss.1995. Tectonics. New York. W. H. Freeman and Company, 415p.

Nelson, G. 1985. A decade of challenge the future of biogeography. Earth Sciences History, 4(2): 187-196.

Oyakawa, O. T., A. Akama. \& A. M. Zanata. 2005. Review of the genus Hypostomus Lacépède, 1803 from Ribeira de Iguape basin, with descriptions of a new species (Pisces, Siluriformes, Loricariidae). Zootaxa, 921: 1-27.

Penha, H. M. 1998. Processos endogenéticos na formação do relevo. Pp. 51-92. In: Guerra, A. J. T \& S. B. Cunha (Eds.). Geomorfologia: uma atualização das bases e conceitos. Rio de Janeiro, Bertrand, 472p.

Petri, S. \& V. J. Fúlvaro. 1983. Geologia do Brasil. São Paulo, Edusp, $631 \mathrm{p}$.

de Pinna, M. C. C. 1998. Phylogenetic relationships of noetropical Siluriforms: historical overview and synthesis of hypotheses. Pp. 279-330. In: Malabarba, L. R., R. E. Reis, R. P. Vari, Z. M. S. Lucena \& C. A. S. Lucena (Eds.). Phylogeny and classification of Neotropical fishes. Porto Alegre, Edipucrs, 603p.

de Pinna, M. C. C. \& W. B. Wosiacki. 2003. Family Trichomycter- 
idae. Pp. 270-290. In: Reis, R. E., S. O. Kullander \& C. J. Ferraris (Eds.). Check list of the freshwater fishes of South and Central America. Porto Alegre, Edipucrs, 729p.

Potter, P. E. 1997. The Mesozoic and Cenozoic paleodrainage of South America: A natural history. Journal of South American Earth Sciences, 10(5-6): 331-344.

Quevedo, R. \& R. E. Reis. 2002. Pogonopoma obscurum: a new species of loricariid catfish (Siluriformes: Loricarridae) from southern Brazil, with comments on the genus Pogonopoma. Copeia, 2002: 402-410.

Raposo, M. I. B. 1995. Episódios intrusivos no Arco de Ponta Grossa, determinados através de um estudo paleomagnético. Revista Brasileira de Geociências, 25(1): 3-19.

Reis, R. E. 1998. Anatomy and phylogenetic analysis of the neotropical callichthyid catfishes (Ostariophysi, Siluriformes). Zoological Journal of the Linnean Society, 124(2): 105-168.

Reis, R. E. 2003. Family Callichthyidae. Pp. 291-309. In: Reis, R. E., S. O. Kullander \& C. J. Ferraris (Eds.). Check list of the freshwater fishes of South and Central America. Porto Alegre, Edipucrs, 729p.

Reis, R. E., C. Weber \& L. R. Malabarba. 1990. Review of the genus Hypostomus Lacépède, 1803 from southern Brazil, with descriptions of three new species (Pisces, Siluriformes, Loricariidae). Revue Suisse de Zoologie, 97(3): 729-766.

Reis, R. E., S. O. Kullander \& C. J. Ferraris. 2003. Check list of the freshwater fishes of South and Central America. Porto Alegre, Edipucrs, 729p.

Ribeiro, A. C., R. C. Benine \& C. A. Figueiredo. 2004. A new species of Creagrutus Günther (Teleostei: Ostariophysi: Characiformes), from the upper Rio Paraná basin, central Brazil. Journal of Fish Biology, 64: 597-611.

Riccomini, C. 1989. O rift continental do sudeste do Brasil. Unpublished PhD Dissertation, Universidade de São Paulo, São Paulo. 256p.

Riccomini, C., L. G. Sant'Anna \& A. L. Ferrari. 2004. Evolução geológica do rift continental do sudeste do Brasil. Pp. 383-405. In: Mantesso-Neto, V., A. Bartorelli, C. D. R. Carneiro \& B. B. Brito-Neves (Eds.). Geologia do continente Sul-Americano: Evolução da obra de Fernando Flávio Marques de Almeida. São Paulo, Editora Beca, 673p.

Riccomini, C. \& M. Assumpção.1999. Quaternary tectonics in Brazil. Episodes, 22(3): 221-225.

Rosa, R. S., N. A. Menezes, H. A. Britski, W. J. E. M. Costa \& F. Groth. 2004. Diversidade, padrões de distribuição e conservação dos peixes da Caatinga. Pp. 135-180. In: Leal, I. R., M. Tabarelli \& J. M. C. da Silva (Eds.). Ecologia e conservação da Caatinga. Recife, Edufpe, 805p.

Saadi, A. 1993. Neotectônica da plataforma brasileira: esboço e interpretações preliminaries. Geonomos 1(1):1-15.

Saadi, A., M. N. Machette, K. M. Haller, R. L. Dart, L. Bradley \& A. M. P. D. Souza. 2002. Map and database of Quaternary faults and lineaments in Brazil. U.S. Geological Survey, OpenFile Report 02-230. (available at http://pubs.usgs.gov/of/2002/ ofr-02-230).

Sabaj, M. H. \& C. J. Ferraris. 2003. Family Doradidae. Pp. 456469. In: Reis, R. E., S. O. Kullander \& C. J. Ferraris (Eds.). Check list of the freshwater fishes of South and Central America. Porto Alegre, Edipucrs, 729p.

Saenz, C. A. T., P. C. Hackspacher, J. C. H. Neto, P. J. Iunes, S. Guedes, L. F. B. Ribeiro \& S. R. Paulo. 2003. Recognition of Cretaceous, Paleocene, and Neogene tectonic reactivation through apatite fission-track analysis in Precambrian areas of southeast Brazil: Association with the opening of the south Atlantic Ocean. Journal of South American Earth Sciences, 15: 765-774.

Schaefer, S. A. 1997. The neotropical cascudinhos: Systematics and biogeography of the Otocinclus catfishes (Siluriformes: Loricariidae). Proceedings of the Academy of Natural Sciences of Philadelphia, 148: 1-120.

Schaefer, S. A. 1998. Conflict and resolution: impact of new taxa on phylogenetic studies of the Neotropical cascudinhos (Siluroidei: Loricariidae) Pp. 375 - 400. In: Malabarba, L. R., R. E. Reis, R. P. Vari, Z. M. S. Lucena \& C. A. S. Lucena (Eds.). Phylogeny and classification of Neotropical fishes. Porto Alegre, Edipucrs, 603p.

Schobbenhaus, C., D. A.Campos, G. R. Derze \& H. E. Asmus. 1984. Geologia do Brasil. Texto explicativo do mapa geológico do Brasil e da área oceânica adjacente incluindo depósitos minerais. Escala 1:2 500000. Brasília, MME-DNPM. 501p.

Silva, J. F. P. 2004. Two new species of Bryconamericus Eigenmann (Characiformes: Characidae) from southern Brazil. Neotropical Ichthyology, 2(2): 55-60.

Souza, C. R. G. \& A. P. Souza. 2002. O escarpamento estrutural de furnas, SP/PR: raro sítio geomorfológico brasileiro. Pp. 299306. In: Schobbenhaus, C., D. A Campos, E. T. Queiroz, M Winge \& M. L. C. Berbert-Born (Eds.). Sítios Geológicos e Palelontológicos do Brasil. Brasília. Departamento Nacional de Produção Mineral (DNPM), 540p.

Souza, L. A. P., M. G. Tessler \& V. L.Galli. 1996. O grabem de Cananéia. Revista Brasileira de Geociências, 26(3): 139-150.

Stiassny, M. \& M. C. C. Pinna. 1994. Basal taxa and the role of cladistic patterns in the evaluation of conservation priorities: A view from freshwater. Pp. 235-249. In: Forey, P. L., C. J. Humphries \& R. I. Vane-Wright (Eds.). Systematics and conservation evaluation. The Systematics Association Special Volume No. 50. Oxford (United Kingdom) Clarendon Press, 466p. Suguio, K., L. Martin, A. C. S. Bittencourt, J. M. L. Dominguez, J. M. Flexor \& A. E. G. Azevedo. 1985. Flutuações do nível relativo do mar durante o Quaternário superior ao longo do litoral brasileiro e suas implicações na sedimentação costeira. Revista Brasileira de Geociências, 15: 273-286.

Tarbuck, E. J. \& F. K.Lutgens. 2002. Earth: an introduction to physical geology. New Jersey, Prentice Hall, 670p.

Thomas, M. F. 1995. Models for landform development on passive margins: Some implications for relief development in glaciated areas. Geomorphology 12: 3-15.

Thomaz-Filho, A. \& A. L. Rodrigues. 1999. O alinhamento de rochas alcalinas Poços de Caldas-Cabo Frio (RJ) e sua continuidade na cadeia Vitória Trindade. Revista Brasileira de Geociências, 29(2): 189-194.

Thomaz-Filho, A., A. M. P. Mizusaki, E. J. Milani \& P. Cesero. 2000. Rifting and magmatism associated with the South America and Africa break up. Revista Brasileira de Geociências, 30(1): 17-19.

Vari, R. P. 1988. The Curimatidae, a lowland neotropical family (Pisces: Characiformes): Distribution, endemism, and phylogenetic biogeography. Pp. 313-348. In: Vanzolini, P. E. \& W. R. Heyer (Eds.). Proceedings of a Workshop on Neotropical Distribution Patterns. Rio de Janeiro. Academia Brasiliera de Ciências, 488p.

Vari, R. P. \& A. S. Harold. 2001. Phylogenetic study of the neotropical fish genera Creagrutus Günther and Piabina Reinhardt (Teleostei: Ostariophysi: Characiformes), with a revision of the cis-andean species. Smithsonian Contributions to Zoology, 613: 1-239. 
Vari, R. P. \& L. R. Malabarba. 1998. Neotropical Ichthyology: An Overview. Pp. 1-11. In: Malabarba, L. R., R. E. Reis, R. P. Vari, Z. M. S. Lucena \& C. A. S. Lucena (Eds.). Phylogeny and classification of Neotropical fishes. Porto Alegre, Edipucrs, 603p.

Vari, R. P. \& S. H. Weitzman. 1990. A review of the phylogenetic biogeography of the freshwater fishes of South America. Pp. 381-393. In: Peters, G. \& R. Hutterer (Eds.). Vertebrates in the Tropics. Proceedings of the International Symposium on Vertebrate Biogeography and Systematics in the Tropics, Bonn, June 5-8, 1989. Alexander Koenig Zoological Research Institute and Zoological Museum, Bonn, 424p.

Vitte, A. C. 2001. Considerações sobre a teoria da etchplanação e sua aplicação nos estudos das formas de relevo nas regiões tropicais quentes e úmidas. Terra Livre São Paulo, 16: 11-24.

Weitzman, S. H \& L. R. Malabarba. 1999. Systematics of Spintherobolus (Teleostei: Characidae: Cheirodontinae) from eastern Brazil. Ichthyological Exploration of Freshwaters, 10(1): $1-44$.
Weitzman, S. H. \& N. A Menezes. 1998. Relationships of the tribes and genera of the Glandulocaudinae (Ostariophysi: Characiformes: Characidae) with a description of a new genus, Chrysobrycon. Pp. 171-192. In: Malabarba, L. R., R. E. Reis, R. P. Vari, Z. M. S. Lucena \& C. A. S. Lucena (Eds.). Phylogeny and classification of Neotropical fishes. Porto Alegre, Edipucrs, 603p.

Weitzman, S. H., N. A. Menezes \& M. J. Weitzman. 1988. Phylogenetic biogeography of the glandulocaudini (Teleostei: Characiformes, Characidae) with comments on the distribution of other freshwater fishes in eastern and southeastern Brazil. Pp. 379-427. In: Vanzolini, P. E. \& W. R. Heyer (Eds.). Proceedings of a workshop on Neotropical distribution patterns. Rio de Janeiro. Academia Brasileira de Ciências, 488p.

Received September 2005

Accepted March 2006 